\title{
О.В. Трофимова
}

\section{ИССЛЕДОВАНИЕ ПУНКТУАЦИИ РУССКОГО ДОКУМЕНТА В ФОРМУЛЯРНОМ АСПЕКТЕ (НА МАТЕРИАЛЕ ТЮМЕНСКИХ ДЕЛОВЫХ ТЕКСТОВ ПОСЛЕДНЕЙ ТРЕТИ ХVIII в.)}

\begin{abstract}
Представлены результаты сопоставительного исследования пунктуации 450 скорописных документов (распорядительных, докладных и просительных) ХVIII в. в динамическом аспекте. Посредством применения грамматически-дипломатического метода выявлена жанровая зависимость в функиионировании знаков препинания на границах и в составе реквизитов формуляра, обнаружена корреляция статуса субъекта письма и пунктуационного оформления коммуникативных интенций субъекта устной речи.

Ключевые слова: пунктуация, история русского языка, грамматика, язык документа, скоропись.
\end{abstract}

\section{Постановка проблемы и метод исследования}

По выражению Н.С. Валгиной, «пунктуацию “изобрели” типографские работники», чтобы расширяющийся благодаря книгопечатанию круг читателей легко воспринимал прочитанное, - следовательно, это была объективно сложившаяся необходимость» [1. С. 7], вызванная вовлечением в коммуникацию дистанцированных адресанта и адресата текста. В лингвистике утвердилось мнение, что русская пунктуация как система небуквенных знаков сложилась в основных своих чертах к XVIII в. [1-3], когда региональная деловая коммуникация осуществлялась посредством рукописных (скорописных) документов. Исследователь русской пунктуации А.Б. Шапиро отмечает, что начиная с введения в России книгопечатания «наблюдается следующее явление: в рукописных текстах знаков препинания мало <..> в печатных же текстах употребляются почти все те знаки, какие употребительны в настоящее время» и по установившимся правилам [3. С. 13] (см. также: [4. С. 68-69]).

Современный исследователь скорописных документов XVIII в., хранящихся в архивных фондах в значительном количестве непрочитанными и отразивших «естественную», «внутреннюю», не отредактированную в соответствии с «внешними» нормами (что свойственно печатным текстам) пунктуационную практику своего времени, еще более дистанцирован от их составителей. Необходимость адекватного прочтения этих документов как условие понимания стоящих за ними ситуаций реальной действительности заставляет «стать на практическую точку зрения», о которой говорят лингвисты, изучающие историю русской пунктуации [3. С. 13; 5. С. 127]. 
Л.Р. Зиндер называл знаки препинания «метаязыковыми семасиограммами», которые «отражают смысловые и синтаксические отношения, заключенные в тексте, но не указывают прямо на его фонетическое оформление - интонацию» [6. С. 73]. По мнению Л.В. Щербы, «система этих знаков возникла стихийно и, строго говоря, никакой единой теории не лежит в её основании», поэтому «совершенно бесплодны все споры о том, на чем построена система русской пунктуации, на грамматике или на интонации» [5. С. 123].

Известно, что в скорописных текстах в XVIII в. знаки препинания «ставятся сравнительно редко», и считается, что их постановка определяется интонационным принципом: «Насколько можно судить по показаниям памятников, в том числе и печатных, а также по грамматическим и орфографическим руководствам XVIII столетия <... о основным поводом для постановки знаков препинания было наличие в речи пауз большей или меньшей длительности» [3. С. 15].

Это общее положение можно конкретизировать, если принять во внимание жанровую природу скорописных документов. Например, среди проанализированных нами тюменских источников екатерининского периода (1762-1796 гг.) все документы таких распорядительных жанров (видов документов), как ордер и предложение, в своей основе имеющих устное волеизъявление регионального начальства (губернатор, воевода, комендант), с преобладанием в формуляре документа элементов-реалий и элементовописаний [7. С. 259], характеризуются наличием знаков препинания; в то же время $71 \%$ купчих крепостей и $27 \%$ челобитных - докладных и просительных документов, составленных в соответствии с устоявшимся абстрактным формуляром с преобладанием в них реалий и формул, знаков препинания не имеют.

Л.В. Щерба считал: «Чтобы хоть немного всё же разобраться в путанице всяческих правил нашей пунктуации, следует <..> спросить себя, что нужно добавить к более или менее длинному тексту < .. > для того, чтобы облегчить его чтение и понимание, если он написан сплошь без всяких делений <..>» [5. С. 127]. В тюменском материале последней трети XVIII в. такие тексты составляют от $35,9 \%$ в 1762-1769 гг. до 14,6\% в 1790-1796 гг. В исследовательских целях «облегчить чтение и понимание» подобных документов (как, впрочем, и имеющих отдельные знаки препинания) возможно, если обратиться «к тем средствам выражения смысловой стороны речи, которые», пишет А.Б. Шапиро, цитируя слова Л.В. Щербы, «легче поддаются учету, - “к словам, их формам, их порядку и т.д.”» [3. С. 54].

Проецируя данные слова на наш материал - скорописные документы, полагаем, что в этот список средств выражения смысла документа следует включить реквизиты, составляющие его формуляр, т.е. применить «грамматически-дипломатический метод», имеющий в основе формулярный анализ, а именно «изучение структуры текста акта»; тем более что, по мнению исследователей, «формулярный анализ может оказаться плодотворным методом исследования не только актового материала, но и других видов письменных источников» [7. С. 259]. 


\section{Характеристика материала исследования}

Материалом настоящего исследования послужил, во-первых, корпус скорописных документов периода правления Екатерины II, опубликованных в издании «Памятники тюменской деловой письменности», всего 381 документ: 347 текстов в [8] и 34 текста - в [9]. Документы составлены преимущественно в Тюмени, Тобольске и в прилегающих к ним округах, частично - в других городах и уездах Сибири, всего в 92 учреждениях: воеводских, губернских, приказных и других канцеляриях, волостных, земских и других судах, духовных правлениях и т.д. [8. С. 594-600]. Во-вторых, при анализе документов отдельных жанров к исследованию привлекаются дополнительные архивные источники (69 документов) из Государственного архива Тюменской области (ГБУТО ГАТО). Таким образом, к исследованию привлечено 450 региональных деловых текстов 1762-1796 гг.

Инициаторы исследуемой письменной деловой коммуникации - это субъекты устной речи:

1) высшие должностные лица, инициировавшие создание наставлений, предложений, указов и других распорядительных документов;

2) подчиненные должностные лица (капралы, сотские, ратманы, целовальники и др.), сообщавшие начальству о тех или иных происшествиях в рапортах и известиях или закреплявшие положение дел в аттестатах, допросах, договорах, журнальных записках, свидетельствах и других докладных документах;

3) просители (бухарцы, разночинцы, крестьяне, ссыльные конфедераты и пр., в большинстве своем неграмотные), от имени которых составлялись просительные документы (просьбы, прошения, челобитные).

Субъектами письма в исследуемых документах выступают профессиональные писцы, а также отдельные грамотные местные жители. Субъекты устной речи оставляли в документе знак своего участия в виде удостоверительной подписи. В соответствии с условным формуляром значительная часть анализируемых документов содержит реквизит «Подпись»; всего в списке подписавших документы по-русски 376 человек. Кроме того, семь документов (допросы, крепости, письма, челобитная) подписаны арабской вязью [8. С. 575-585]. Сведений о том, кем текст записан, чаще всего в документе нет; однако иногда можно обнаружить записи типа:

$<\ldots>$ Сие о ${ }^{\sigma}$ яснение по прозбе тюменского мещанина Василья Кадошникова писаль ј рукя приложи ${ }^{n}$ Тюменской гарнизонной команды по прапо $^{p}$ щикъ Данила Рябовъ [8. С. 244].

Исключение представляют крепости (купчие, кортомные, закладные и др.) и челобитные, в которых сведения о субъекте письма были обязательны, так как составляли один из реквизитов конкретного формуляра документа, например:

$<\ldots>$ сию закла ${ }^{\partial}$ нүю писа ${ }^{n}$ и запйса ${ }^{n}$ Тюменской воево ${ }^{\partial}$ ской ка ${ }^{\mu}$ целярий копейсть Яко ${ }^{6}$ Шероглазовъ; < ..> сию кортомную писа ${ }^{r}$ и записалъ 
крепостны ${ }^{x}$ делъ по ячеи Василеи Стояно ${ }^{6}$ скои $<\ldots>$; сию купчую кре-

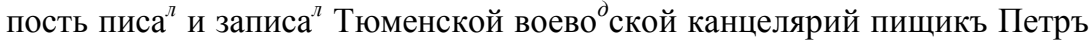
Саннико $^{B}$ [8. С. 189, 190, 194];

<..> к поданию надлежитъ в Тюменскую воевоцкую канцелярию челобитную писа ${ }^{n}$ тюменски ${ }^{x}$ выписны ${ }^{x}$ казако ${ }^{b}$ сотникъ Семенъ Тверитиновъ; <..> к поданию на лежитъ в Тюменскую воеводскую канцелярию сию челобитную писа ${ }^{л}$ оной же канцелярий копеистъ Никифоръ Загорской; [8. С. 516, 527].

В списке из 30 атрибутированных субъектов письма - копиисты, канцеляристы и подканцеляристы, писчики, подьячий, писарь, писец, а также разночинцы, казаки, прапорщик и ямщик [8. С. 574-575]. Служители канцелярий в силу должностных обязанностей вносили в полученные документы пометы (например, в ответы на требования о ценах на продовольствие), подписывая их, как это сделали, в частности, копиист и два канцеляриста Тюменской воеводской канцелярии на одобрении, выданном 10 июня 1781 г. крестьянину деревни Колугиной Д. Пустовских, об отпуске его для рыбного промысла (единственный знак препинания здесь - точка с запятой, маркирующая границу текстов не только с разной коммуникативной целью: запрос информации и сообщение информации, но и с разными субъектами письма):

$<\ldots>$ Тюменской воево ${ }^{\partial}$ ской канцелярий канцеляриста ${ }^{M}$ и подканцеляристо $^{m}$ справитца не имеьтца $^{n}$ до вышеписанного крестьянина Дми ${ }^{m-}$ рея Пустовски ${ }^{x}$ каки ${ }^{x}$ де $^{x}$ и казенного взыскания и что по справке окажетца по ${ }^{\partial}$ си $^{n}$ подписать ј возврати ${ }^{m b}$ в подушное повы ${ }^{m b}$ е копеисть Никифоръ Загорской;

На сие по ${ }^{c}$ пра ${ }^{s}$ ке в соляно ${ }^{M}$ прихо ${ }^{\partial}$ но $^{M}$ и ко ${ }^{p}$ че $^{M}$ но $^{M}$ повы ${ }^{m b} я^{x}$ по ${ }^{c}$ правке оказало ${ }^{c}$ что до написа ${ }^{t}$ ного крестьянина Пустовски ${ }^{x}$ де $^{n}$ и казенного взыскания не состои ${ }^{m}$ канцеляристь Осипъ Нестеровъ

В военно ${ }^{M}$ судно $^{M}$ розыскно $^{M}$ ј правианско $^{M}$ повытьяхъ до написаннова в сеи спра ${ }^{B}$ ке крестьянине Пгстовски ${ }^{x}$ дель и взыскания не имъитца подписа $^{r}$ канцеляристь Василеи Чүрило ${ }^{6}$ [8. С. 256].

Если адресант был неграмотен, подпись за него ставил другой человек или же, в случае неграмотности должностного лица, прикладывалась печать, например:

$<\ldots>$ к сему доношению вместо са ${ }^{л}$ дата Михаила Каминскаго ево прозбои березавско ${ }^{u}$ казачеи пятидеся ${ }^{m}$ никъ Петръ Старковъ руку приложилъ; $<\ldots>$ за безграмо ${ }^{m}$ ствомъ старостъ и выборныхъ у сего приложена волостнаго суда печать [8. С. 82].

В подавляющем большинстве документов фиксируем, таким образом, два почерка: первым текст записан, вторым (иногда и третьим, четвертым), принадлежащим субъекту речи, - подписан, т.е. тексту придана правовая сила официального документа. Вторыми почерками оставили в документах 
память о себе, помимо указанных выше чиновников, дворянский заседатель, пономарь, посадский, соляной пристав, цеховой, штатный драгун, экспедитор и др.

В корпусе немногочисленны тексты, в которых субъект речи и субъект письма совпадают (как в пометах к одобрению выше). Это, например, доношение тюменского купца М. Прасолова о передаче им собственного дома малому народному училищу; объявление копииста Ф. Мосягина о принесенном в канцелярию «сумнительном» неподписанном письме; рапорт прапорщика Ф. Лекирова о сбежавших колодниках или писаря Фоминского волостного суда В. Даровнятнова о получении в суде указа о штрафах за небытие на исповеди [8. С. 96, 210, 426, 428] и некот. др.

Представление о насыщенности документов пунктуационными знаками, в том числе в диахроническом аспекте, можно получить из табл. 1.

Т а блли ц 1

Количественное распределение знаков препинания

\begin{tabular}{|c|c|c|c|c|c|c|c|}
\hline \multirow[b]{2}{*}{$\begin{array}{l}\text { Период, } \\
\text { годы }\end{array}$} & \multirow{2}{*}{$\begin{array}{c}\text { Текстов со } \\
\text { знаками } \\
\text { препина- } \\
\text { ния, \% }\end{array}$} & \multicolumn{5}{|c|}{ Количество знаков в тексте } & \multirow[b]{2}{*}{$\begin{array}{c}\text { Текст максимального } \\
\text { объема; количество } \\
\text { слов и знаков в нем }\end{array}$} \\
\hline & & $1, \%$ & $\begin{array}{c}2-10 \\
\%\end{array}$ & $\begin{array}{c}11-20 \\
\%\end{array}$ & $\begin{array}{c}21-30 \\
\%\end{array}$ & $\max$. & \\
\hline $1762-1769$ & 64,1 & 35,09 & 42,1 & 8,77 & 7,02 & 35 & $\begin{array}{c}4103 \text { (выписка); } \\
32 \text { зн. } \\
\end{array}$ \\
\hline $1770-1779$ & 87,5 & 9,89 & 61,5 & 15,38 & 8,79 & 109 & $\begin{array}{c}4944 \text { (определение); } \\
109 \text { зн. }\end{array}$ \\
\hline $1780-1789$ & 86,7 & 12,24 & 60,2 & 15,3 & 9,18 & 265 & $\begin{array}{c}2322 \text { (описание); } \\
265 \text { зн. }\end{array}$ \\
\hline 1790-1796 & 85,4 & 18,75 & 51,6 & $17,19 \%$ & 12,5 & 44 & $\begin{array}{c}1808 \text { (кондиции); } \\
23 \text { зн. }\end{array}$ \\
\hline ИТОГО & 81,4 & 17,1 & 55,48 & 14,52 & 9,35 & $3,55 \%$ & $100 \%$ \\
\hline
\end{tabular}

Демонстрируемая материалами таблицы тенденция к увеличению количества знаков препинания в документах коррелирует, вероятно, с расширением к концу XVIII в. числа субъектов письменной деловой коммуникации в связи с определенным ростом грамотности населения.

\section{Теоретические основания и гипотеза исследования}

Исследуемые тюменские документы 82 жанров представляют деловую коммуникацию ограниченного числа участников (преимущественно профессиональных адресантов и адресатов), действовавших в достаточно типичных экстралингвистических обстоятельствах, при которых, по словам А.Б. Шапиро, «...не было особой нужды в тщательном обозначении всех сторон письменного текста <..>. Чтец, в силу профессиональной опытности, справлялся более или менее удовлетворительно с любым текстом тем более, что как жанровые, так и стилистические разновидности произведений письменности были в то время не так уж многочисленны и разнообразны» [3. С. 6]. 


\section{Сопоставление фрагментов из «Соборного уложения»}

\begin{tabular}{|c|c|c|}
\hline $\begin{array}{c}\text { Соборное уложение } 1649 \text { г. } \\
\left(\mathrm{O}^{1}\right) \\
\text { [https://dlib.rsl.ru/viewer/010 } \\
\text { 02429078\#?page=138] }\end{array}$ & 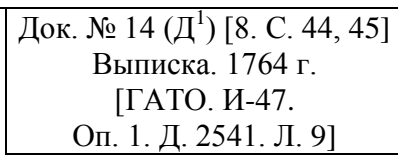 & $\begin{array}{c}\text { Док. № } 144\left(\text { Д }^{2}\right) \text { [8. С. 302] } \\
\text { Определение. } 1777 \text { г. } \\
\text { [ГАТО. И-47. Оп. } 1 . \\
\text { Д. 3588. Л. } 22 \text { об.] }\end{array}$ \\
\hline $\begin{array}{c}\text { [https://dlib.rsl.ru/viewer/010 } \\
\text { 02429078\#?page }=143 \text { ] }\end{array}$ & $\begin{array}{l}\text { АвСоборномъ Уложение } 10^{\ddot{u}} \\
\text { главы внижеявленныхъ пун } \\
\text { тахъ напечатано }:|<\ldots>:|\end{array}$ & $\begin{array}{l}<\ldots>\text { аСоборного Уложения } \\
10 \text { главы вста }{ }^{m} \text { я }^{x} \text { напечатано }\end{array}$ \\
\hline 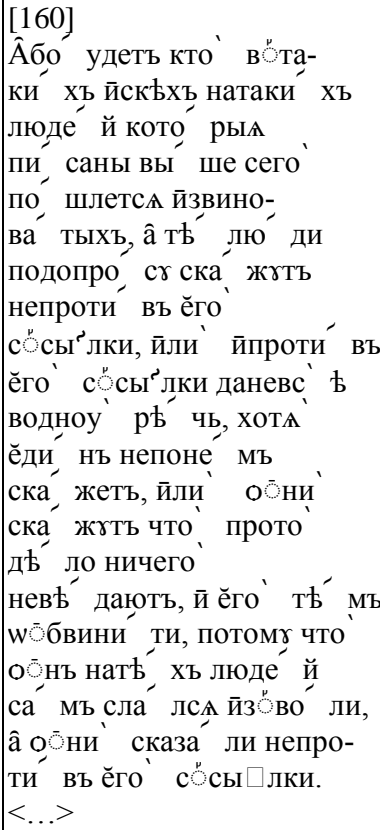 & 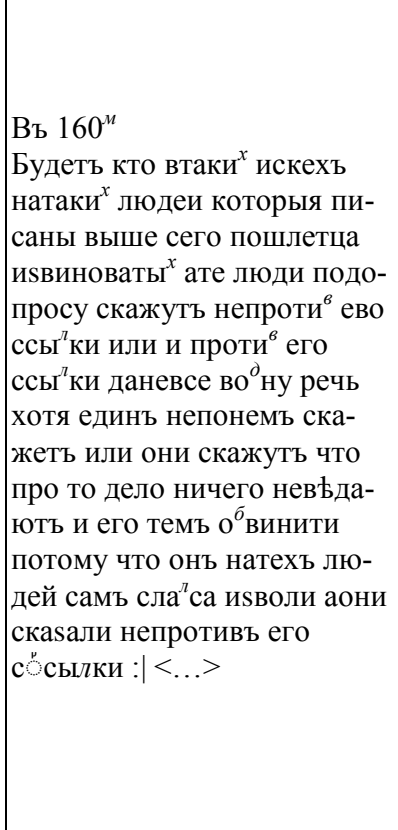 & 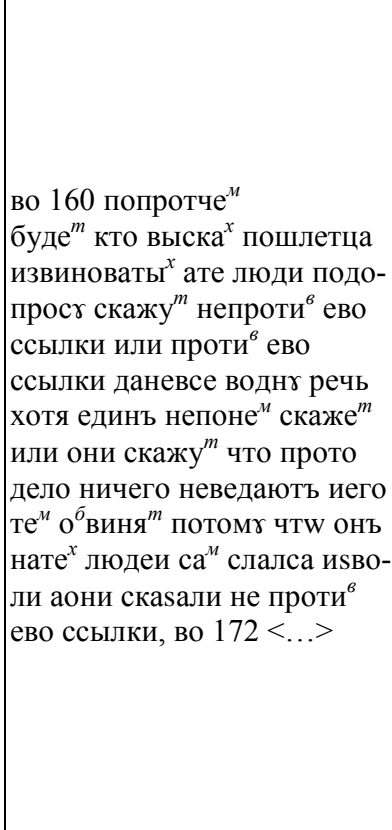 \\
\hline 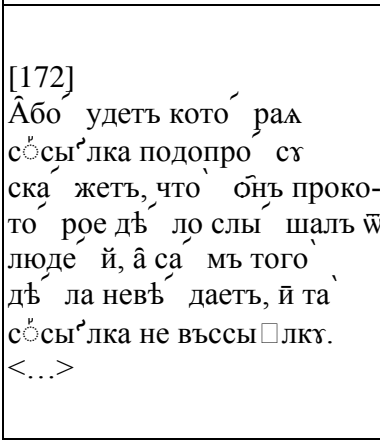 & 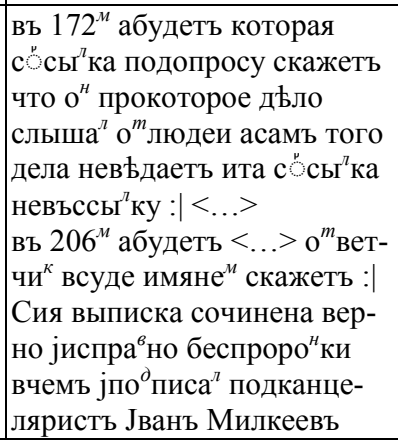 & 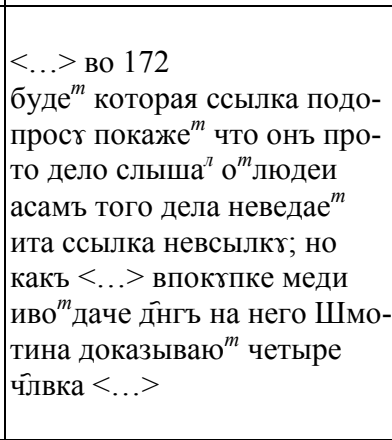 \\
\hline
\end{tabular}


Сопоставление фрагментов из «Морского устава»

\begin{tabular}{|c|c|}
\hline \multirow{2}{*}{$\begin{array}{c}\text { Морской устав } 1720 \text { г. }\left(\mathrm{O}^{2}\right) \\
\text { [https://runivers.ru/bookreader/book9814/\#p } \\
\text { age/80/mode/1up] }\end{array}$} & $\begin{array}{c}\text { Док. № } 345 \text { [8. С. 533] }\left(Д^{3}\right) \\
\text { Экстракт следственного дела. } 1776 \text { г. } \\
\text { [ГАТО. И. 47. Оп. 1. Д. } 4457 . \text { Л. } 2 \text { об., 3] }\end{array}$ \\
\hline & $\begin{array}{l}\text { вкниге пятой морскаго устава напечата- } \\
\text { но: «16» главы во «120"» пункте } \\
\end{array}$ \\
\hline $\begin{array}{l}\text { 120. Ежели кто женской полъ изнасиль- } \\
\text { ствуетъ и освидътельствуется: за то оной } \\
\text { живота лишенъ да будетъ, или въчно на } \\
\text { галеру посланъ, по силъ дъла. }\end{array}$ & $\begin{array}{l}\text { ежели кто женскои поль изнасилствуе }{ }^{m} \\
\text { иосвидетелствуется зато онои живота лише }^{H} \\
\text { дабуде }^{m} \text { или вечно нагалеру посланъ посиле } \\
\text { дела: }\end{array}$ \\
\hline $\begin{array}{l}\text { Tолк. Скверныя женщины, обыкновенно } \\
\text { избывая своего стыда, предлагаютъ, что } \\
\text { насильствованы: тогда судьъ ихъ, такому } \\
\text { предложенію вскорђ не надлежитъ } \\
\text { върить, но подлиннъе о правдъ вывьды- } \\
\text { вать и чрезъ сіе о насилиі можно осви- } \\
\text { дътельствовать, егда изнасильствованная } \\
\text { свидътелей имеетъ, что оная съ великимъ } \\
\text { крикомъ другихъ на помощь призывала. } \\
\text { А ежели сіе дъло <...> }\end{array}$ & 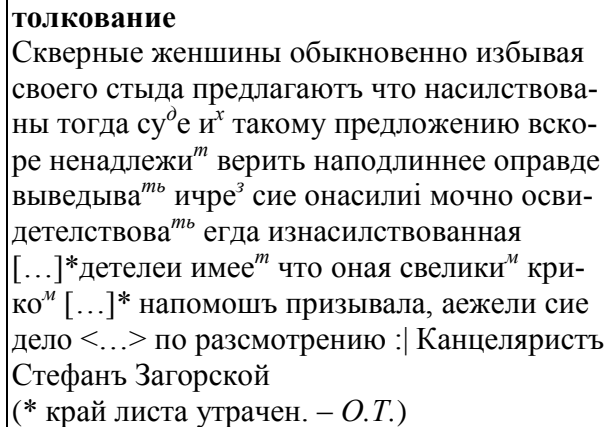 \\
\hline
\end{tabular}

Современные исследователи полагают, что жанровые формы во многом определяют мышление и дискурсивное поведение субъекта речи, и выделяют фрейм-модели речевых жанров - «наборы (классы) средств, объединенных общностью прагматической роли в организации дискурса соответствующего речевого жанра» [10. С. 21]. Это понятие можно соотнести с понятием формуляра документа. Вероятно, фрейм-модели лежат в основе восприятия любого текста: «...текст, содержащий информацию, рассчитан на понимание, а значит, на извлечение этой информации» [11. С. 72]. Таким образом, если любой текст - это сформированная у читателя «ментальная модель», если «текст как правильно организованная форма коммуникации, как сообщение, уже содержит в себе самом некие единицы, средства, сигналы и т.п., достаточные и необходимые для построения на его основе правильной и осмысленной модели» [11. С. 73], то документ в ситуации деловой коммуникации узкого круга «своих», преимущественно профессиональных субъектов речи и письма, в принципе, может быть «свободен» от метаязыковых знаков препинания, которые могут вносить в текст (с учетом индивидуальности интонаций говорящего и пунктуационной выучки пишущего) субъективные смыслы, «надстраивающиеся» над «общей» основой. Следовательно, во-первых, расширение с течением времени границ документооборота и вовлечение в него большего числа грамотных и опытных коммуникантов; во-вторых, преемственность, постепенно формирующая нормы деловой письменности с опорой на социально значимые юридические тексты [12. С. 297]; в-третьих, влияние печатных 
текстов на «стихийное» употребление в рукописных документах знаков препинания приводит к формированию надстилевой русской пунктуационной системы, по словам Л.В. Щербы, «французского типа», с выражением посредством знака «смысловых нюансов (зачастую чисто идеографически, т.е. вне всякой связи с интонацией)» (цит. по: [3. С. 54]).

\section{Региональная «норма»}

Известно, что, даже стараясь переписать текст с образца, пишущий может допустить ошибки, ибо он часто «не видит» текст, руководствуясь собственным представлением о правильном (или значимом - с точки зрения передачи смысла) написании. Документы анализируемого в статье корпуса позволяют провести своеобразный «эксперимент», сравнив версии написания одного и того же текста.

Так, оказалось, что 160-я и 172-я статьи Соборного уложения 1649 г. включены в состав двух документов Тюменской воеводской канцелярии (выписки из следственного дела и определения). Сравнив оригинальный текст $\left(\mathrm{O}^{1}\right)$ и цитаты в документах $\left(Д^{1}, Д^{2}\right)$, обнаруживаем (помимо графических: традиционного для скорописи слитного написания служебных частей речи со знаменательными (при публикации примеров далее вне данных таблиц их разделяем), наличия выносных букв, а также мены букв «њ» и «е», «и» и «ј», «й» и «и», «я» и «у») значительные пунктуационные различия (табл. 2). Таблица делает наглядным следующее:

$\mathrm{O}^{1}-10$ запятых и две точки в конце предложений (и статей в целом); в тюменских документах - только финальные знаки в конце каждой цитаты;

$Д^{1}-$ знак :| (срока), как и в конце каждой из восьми процитированных статей Соборного уложения, включенных в заключительную часть выписки из следственного дела, в том числе в абсолютном конце текста перед реквизитом «Подпись», записанным другим почерком;

$Д^{2}$ - запятая как знак перечисления равноценных текстовых блоков (заимствований из чужого текста) в отличие от точки с запятой - знака границы сфер разных субъектов речи (столичного законодателя / местного чиновника) и текстов с разными типами информации (обобщенная / конкретная) и модальности (ирреальная, долженствования, / реальная, в настоящем расширенном времени).

Представляется, что тюменские канцеляристы списывали статьи закона с какой-либо копии, которой предшествовала целая очередь переписываемых копий, и главным в этой ситуации деловой коммуникации оказалось представить чужой текст в его данности (даже в случае отдельных лексических пропусков и замен, как в $Д^{2}$ ).

Приведем еще один пример - цитирование в тюменских документах «Морского устава» Петра I от 13 января 1720 г. (табл. 3). Выявленные пунктуационные различия:

$\mathrm{O}^{2}-$ девять запятых, два двоеточия и две точки;

$Д^{3}$ - «проигнорированы» внутренние (внутри двух полипредикативных единиц) знаки препинания; двоеточие заменяет первую точку оригинала 
при смене речевой интенции (сообщение $\rightarrow$ истолкование); запятая - вторую точку оригинала внутри текста-толкования. В структуре документа цитата так же заканчивает текст, и перед реквизитом «Подпись», как и в $Д^{1}$, использована срока.

\section{Набор знаков в исследуемом корпусе}

В опубликованном 381 документе нашли отражение 12 знаков препинания. Помимо девяти одинарных знаков (см. табл. 4), это редкое в документах абзацное членение и парные знаки - квадратные и фигурные скобки, например:

1771 году июля 17 дня Тюменскаго гезду Якиярски ${ }^{x}$ юрть жите служилой татаринъ Јсакъ Надыро ${ }^{6}$ да $^{n}$ сие верящее писмо тюменскому

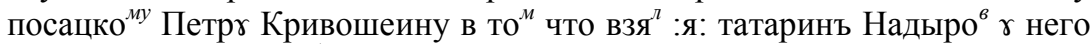
Кривошеина [займо ${ }^{\sigma}$ разно денегъ] три рябли деся ${ }^{m}$ копеекъ для свои ${ }^{x}$ нео $^{6}$ ходимы ${ }^{x}$ нуждь $<\ldots>$ [8. С. 332].

Т а бл и ц а 4

Употребление одинарных знаков препинания в 1762-1796 гг.

\begin{tabular}{|c|c|c|c|c|c|c|c|c|c|c|c|}
\hline \multirow{2}{*}{ 1762-1796 гг } & \multicolumn{3}{|c|}{ Текстов } & \multicolumn{8}{|c|}{ Пунктуационных знаков } \\
\hline & всего & $3 \Pi-$ & $3 \Pi+$ & , & : & $:$ & ; & . &. $\mid$ и .|. & ? & $!$ \\
\hline $\begin{array}{c}\text { Абсолютное } \\
\text { число }\end{array}$ & 381 & 71 & 310 & 1658 & 487 & 215 & 412 & 48 & 31 & 3 & 3 \\
\hline$\%$ & 100 & 18,6 & 81,4 & 58 & 17,1 & $\mathbf{7 , 5}$ & 14,4 & $\mathbf{1 , 7}$ & 1,1 & 0,1 & 0,1 \\
\hline
\end{tabular}

Достаточно частотны парные кавычки, непоследовательно употребляемые преимущественно при введении даты, например: прошлого «1775» го ${ }^{\partial y}$, в том числе как одинарный знак: прошлаго 1772» года августа 10» дня; а также знак точки для обозначения сокращенного написания ч. (числа), например: В баталионъ соо щено 25: ч.; Сего ноября, 26. ч. в Тюменское уездное казначеиство представи и др.

Данные табл. 4 свидетельствуют, что на протяжении 34 лет екатерининского этапа российской истории, во-первых, оставалось значимым (к концу периода - 18,6\%) количество текстов, не имеющих знаков препинания; вовторых, минимальным было употребление знаков конца предложения, в том числе точки. Исключительность для деловой письменности вопросительного и восклицательного знаков как показателей субъективной модальности подтверждается тем, что употреблением (причем тройным) каждого из них отмечено в корпусе только по одному документу, а именно: запрос необходимых сведений по пунктам (подчеркивающий значимость для адресанта каждой информации и требующий от адресата не упустить её) в предложении тобольского губернатора Евгения Кашкина от июля 1782 г.:

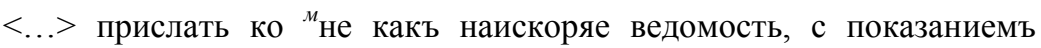
прежней ихъ службы? Какого они поведения? Не были ль въ штрафахъ и подозренияхъ? < ..> [8. С. 134]. 
и «крик души» болеющего за дело уездного доктора Тюменской и Туринской округ в его сообщении от ноября 1792 г.:

$<\ldots>$ понынъ какъ гобшпиталя такъ и содержанія аптеки места в городъ Тюмени не построено и совсемъ не имъется! <..> с великою нуждою ихъ излечать можно! <..> О чемъ Тюменская комендантская канцелярія благоволить быть известна и какое по семх положеніе последхетъ меня писменно уведомить! ноября «9» дня «1792 го» года.| Докторъ Иванъ Линденбергъ [8. С. 471-472].

\section{Формулярный аспект анализа документов разных жанров}

Документы 20 жанров из 82, вошедших в корпус, имеют в формуляре начальный протокол, как правило, представленный отдельным абзацем, включающий реквизиты «Адресант» $(\mathrm{S})$, «Адресат» (А) и «Самоназвание документа» $(\mathrm{N})$, при этом последовательность реквизитов варьируется в зависимости от жанра. В качестве иллюстрации рассмотрим деловые тексты четырех жанров, представленных в опубликованном материале более чем десятью документами.

Так, в предложениях, частно-публичных документах рекомендательного вида [6. С. 256], на первом месте - реквизит «Адресант» (S), называющий субъекта устной речи (из первой группы), что соответствует коммуникативному назначению документа, ср. в «Словаре Академии Российской»: ‘4) Въ приказн. нарғч. Отъ уполномоченныхъ властїю или особливою довђренностїю чиновниковъ, какъ то намЂстниковъ, правителей и прочихъ начальниковъ и прокуроровъ подчиненнымъ, или по должности къ нимъ относящимся присутственнымъ мъстамъ, письменное или словесное предписанїе, напоминанїе, представленїе по дъламъ о изполненїи и учиненїи чего' [13. Стб. 1284, 1285] (см. также [9. С. 129]).

В доношениях, делопроизводственных документах [7. С. 395], составлявшихся от нижестоящего на административной лестнице коммуниканта (из второй группы субъектов речи), первый реквизит - «Адресат» (А); эта социальная иерархия закреплена в словарных толкованиях термина: '1. Письменное донесенїе или прошенїе о чемъ, подаваемое въ присутственныя мъста. 2. Извђщенїе отъ нижняго мъста вышшему о чемъ' [14. Стб. 496] (см. также [15. С. 48; 16. С. 212; 9. С. 12]). То же - в объявлениях, которые могут быть отнесены как к докладным, так и к просительным (с субъектами речи из третьей группы) документам; в словаре объявление определяется как '2) Писменное извъщеніе о чемъ въ какое либо судебное мЂсто’ [17. Стб. 1629] (см. также [18. С. 137; 19]).

В промемориях, относящихся к докладным документам межканцелярского типа [20-22], в абсолютном начале документа - реквизит «Самоназвание документа»; в отличие от других документов, содержащих начальный блок реквизитов, переход к следующему, основному, текстовому блоку в них графически не отмечен.

Текстовый блок в формуляре большей части документов представляет собой полипредикативную конструкцию с маркерами союзной (сочини- 
тельной и подчинительной), реже - бессоюзной связи предикативных частей, которую часто невозможно механически разбить на отдельные простые и сложные предложения, не нарушив грамматических связей исходного связного текста, не имеющего, как правило, и выраженного формального показателя своего начала - прописной буквы в первом слове.

Текстовый блок значительной части документных жанров имеет первой казусную (констатирующую) часть (К), содержащую информацию (в том числе со ссылками на другие документы), необходимую для принятия волевого решения, второй - прагматическую часть (Р), в которой сформулировано волеизъявление (вводимое в текст посредством глагольных форм предлагаю, извольте, приказали, определено, прошу, благоволит и т.д.). Эти части формуляра различаются в модальном (реальная / ирреальная модальность) и коммуникативном (сообщение о ситуации / намерение изменить ситуацию силами одиночного адресата или иерархии адресатов) отношении. Как правило, граница казусной и прагматической частей отмечена скрепой, чаще всего выделенной буквами большего размера, функцию которой выполняет предложно-падежная форма местоимения с вмещающим значением ТОГО РАДИ (варианты: того для, чего ради, и для того, а потому и др.) [23].

На границе текстового блока и удостоверительной части с реквизитом «Подпись» $\left(\mathrm{S}_{\mathrm{p}}\right)$, как правило, происходит смена субъектов письма, но в большинстве случаев знак препинания об этом не предупреждает; как правило, отсутствует знак, отделяющий реквизит «Дата» (D); при наличии такового это может быть также любой знак препинания. В документах разных жанров порядок реквизитов «Дата» $(\mathrm{D})$ и «Подпись» $\left(\mathrm{S}_{\mathrm{p}}\right)$ различен.

\section{Пунктуационный анализ границ реквизитов в документах}

В качестве иллюстрации рассмотрим по три документа каждого из представленных выше жанров: предложение, доношение, объявление, промемория. При их публикации в табличном варианте обозначим косой чертой / конец строки в оригинале, звездочкой * отметим смену почерка. Каждый документ, представленный в таблицах с указанием реквизитов и количеством предикативных частей, предварим информацией о «пунктуационной ситуации» в нем: об общем количестве знаков препинания (имеющемся в оригинале - в абсолютном и относительном исчислении - и возможном в соответствии с современными правилами), а также об употреблении каждого знака отдельно. Текстовый блок представим фрагментами предикативных частей, позволяющими проанализировать индивидуальный формуляр документа, с перечнем всех документов, упоминаемых в казусной и прагматической частях (названия которых выделены полужирным шрифтом, как и скрепы на границе частей). Кроме того, рассчитаем условную «силу знака»: количество слов от знака до знака в исходной пунктуационной картине - и в случае применения современных пунктуационных правил, которые бы облегчили исследователю восприятие содержания до- 
кумента, с указанием коэффициента ${ }^{\mathrm{K}}$ трудности восприятия текста с оригинальной пунктуацией.

\section{Предложения}

Кроме 11 опубликованных [8. С. 256-262; 9. С. 128-140], в материал исследования входят семь архивных источников [24], итого 18 документов 1765-1793 гг. Три из них представлены в табл. 5.

Т а бли ц а 5

\section{Предложения}

\begin{tabular}{|c|c|c|c|c|c|c|c|c|c|c|c|c|c|c|}
\hline $1 / 1$ & \multicolumn{14}{|c|}{ Предложение, 1765 г. [8. С. 356, 357] } \\
\hline \multicolumn{2}{|c|}{$\begin{array}{c}\text { Рекви- } \\
\text { зит }\end{array}$} & \multicolumn{11}{|c|}{ Количество в документе } & \multirow{3}{*}{\multicolumn{2}{|c|}{$\begin{array}{c}\text { «Сила знака»: } \\
\text { кол-во слов / } \\
\text { кол-во знаков }\end{array}$}} \\
\hline \multirow{4}{*}{\multicolumn{2}{|c|}{$\begin{array}{c}\text { Рекви- } \\
\text { зит: } \\
\text { предика } \\
\text { тивная } \\
\text { часть }\end{array}$}} & \multirow{3}{*}{ слов } & \multicolumn{4}{|c|}{ знаков всего } & \multicolumn{6}{|c|}{ употреблений } & & \\
\hline & & & \multirow[b]{2}{*}{ есть } & \multirow{2}{*}{$\begin{array}{c}\text { могло } \\
\text { бы } \\
\text { быть }\end{array}$} & \multicolumn{2}{|c|}{\begin{tabular}{c|} 
из них \\
совпадают по \\
\end{tabular}} & \multirow[b]{2}{*}{, } & \multirow[b]{2}{*}{$:$} & \multirow[b]{2}{*}{$: \mid$} & \multirow{2}{*}{\multicolumn{2}{|c|}{; }} & \multirow[b]{2}{*}{$\cdot|\cdot|$} & & \\
\hline & & & & & месту & \begin{tabular}{|c|} 
функ- \\
ции
\end{tabular} & & & & & & & есть & $\begin{array}{c}\text { могло } \\
\text { бы быть }\end{array}$ \\
\hline & & 225 & $\begin{array}{c}5 \\
(20,8 \%) \\
\end{array}$ & 24 & 4 & 4 & \multicolumn{2}{|c|}{$3-$} & $-\mid-$ & \multicolumn{2}{|c|}{-2} & - & 56,25 & $9,38\left(6^{\mathrm{K}}\right)$ \\
\hline \multicolumn{15}{|c|}{\begin{tabular}{l|l}
$\mathrm{S}$ & $\begin{array}{l}\text { Генералъ маіора лейб гвардіи примеръ маіора / и сибирскаго губернатора Чиче- } \\
\text { рина }\end{array}$
\end{tabular}} \\
\hline \begin{tabular}{l|l} 
A & B \\
\end{tabular} & \multicolumn{14}{|c|}{ в Тюме ${ }^{H} /$ скүю воеводскүю канцелярію. / } \\
\hline \begin{tabular}{l|ll}
$\mathrm{N}$ & $\mathbf{I}$ \\
\end{tabular} & \multicolumn{14}{|c|}{ Предложеніе / } \\
\hline \begin{tabular}{l|l} 
K: & $\mathrm{I}$ \\
1,2 & $\mathrm{I}$
\end{tabular} & При & $\begin{array}{l}\mathrm{I} \text { прођз } \\
\mathrm{Tъ} / \text { усг }\end{array}$ & $\begin{array}{l}\text { зде моемъ } \\
\text { мотренъ N }\end{array}$ & $\begin{array}{l}\text { из Табо. } \\
\text { иною вес }\end{array}$ & 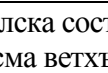 & $\begin{array}{l}\text { тоящей / } \\
\text { о }{ }^{m} \text { кото }\end{array}$ & $\begin{array}{l}\text { здњ } \\
\text { рагс }\end{array}$ & $\begin{array}{ll}\mathrm{scb} \text { I } \\
\mathrm{O}<\mathrm{s}\end{array}$ & IOCT] & $\begin{array}{l}\text { рое } \\
\text { есть }\end{array}$ & $\begin{array}{l}\text { нной } \\
\text { н неб }\end{array}$ & $\begin{array}{l}\text { й чр } \\
\text { безо }\end{array}$ & $\begin{array}{l}\text { езъ ре } \\
\text { паснос }\end{array}$ & $\begin{array}{l}\text { чкү Тюменкя } \\
\text { ти. }\end{array}$ \\
\hline $\mathrm{P}: 3[1$ & TOI & $\Gamma \mathbf{O} / \mathbf{P}$ & АДИ пре & дллагаю & & & & & & & & & & \\
\hline $4-\left.15\right|_{\mathrm{K}} ^{\mathrm{C}}$ & $\begin{array}{l}\text { что }^{6} \\
\text { канг }\end{array}$ & $\begin{array}{l}\sigma_{0}<\ldots> \\
\text { целяри }\end{array}$ & $\begin{array}{l}\text { репорто } \\
\text { ия оставл }\end{array}$ & $\begin{array}{l}\text { вать на } \\
\text { ена / бы }\end{array}$ & $\begin{array}{l}\text { что без } \\
\text { ть не им }\end{array}$ & $\begin{array}{l}\text { особлив } \\
\text { ьетъ }\end{array}$ & & & & & & & каз & ево ская \\
\hline $\mathrm{D}$ & февн & раля д & цня 1765 г & ода* & & & & & & & & & & \\
\hline $\mathrm{S}_{\mathrm{p}}$ & Д Ч & ичери & & & & & & & & & & & & \\
\hline $2 / 2$ & & & & Пре & дложенг & ne, 1766 & г. [ & $8 . \mathrm{C}$ & .35 & $7-3$ & $359]$ & & & \\
\hline $\begin{array}{r}\text { Рекві } \\
\text { зит }\end{array}$ & & & & Коли & чество в & докуме & нте & & & & & & «Си & ла знака»: \\
\hline & & & & знаков & всего & & & упо & трес & блег & ний & & кол-в & слов / кол- \\
\hline $\begin{array}{r}\text { РеквІ } \\
\text { зит: }\end{array}$ & & слов & & могло & $\begin{array}{r}\text { из } \\
\text { совпад }\end{array}$ & $\begin{array}{l}\text { них } \\
\text { aет по }\end{array}$ & & & & & & & & знаков \\
\hline $\begin{array}{r}\text { преди } \\
\text { тивн }\end{array}$ & $\begin{array}{l}\text { ика- } \\
\text { ная }\end{array}$ & & есть & $\begin{array}{c}\text { оы } \\
\text { быть }\end{array}$ & месту & \begin{tabular}{|c|} 
функ- \\
ции \\
\end{tabular} & , & $:$ & $: \mid$ & ; & - & $\cdot \mid$ & есть & $\begin{array}{c}\text { могло бы } \\
\text { быть }\end{array}$ \\
\hline част & & 338 & $\begin{array}{c}7 \\
(24,1 \%)\end{array}$ & 29 & 6 & 3 & 5 & - & - & 1 & - & 1 & 56,3 & $11,66\left(4,8^{K}\right)$ \\
\hline S & $\begin{array}{l}\mathrm{O}^{m} \mathrm{~F} \\
\text { чева }\end{array}$ & $\begin{array}{l}\text { надвор } \\
\mathrm{a}\end{array}$ & рного сов & етника j & Сибирс & кой губе & & & & & & & тов & ища Рыка- \\
\hline \begin{tabular}{l|l}
$\mathrm{A}$ & $\mathrm{E}$ \\
\end{tabular} & в Тң & оменс & кую воев & о $/$ скую & канцеля & грию / & & & & & & & & \\
\hline \begin{tabular}{l|l}
$\mathrm{N}$ & $\mathrm{I}$ \\
\end{tabular} & Пре & едлож & ение, / & & & & & & & & & & & \\
\hline K: $1: \begin{array}{l}\mathrm{I} \\
\mathrm{I} \\
\mathrm{z}\end{array}$ & $\begin{array}{l}\text { Въ } \\
\text { гвар } \\
\text { чим }\end{array}$ & $\begin{array}{l}\text { ордерс } \\
\text { одиі пр } \\
\text { Iъ пре }\end{array}$ & $\begin{array}{l}\text { е его прег } \\
\text { римеръ м } \\
\text { дложено; }\end{array}$ & $\begin{array}{l}\text { восходиา } \\
\text { aiopa / j }\end{array}$ & $\begin{array}{l}\text { гелства I } \\
\text { ковалер }\end{array}$ & $\begin{array}{l}\text { г̄дна ген } \\
\text { а Денисс }\end{array}$ & & & & & & & $\begin{array}{l}\text { ского } \\
\text { на меж }\end{array}$ & $\begin{array}{l}\text { губернатора } \\
\text { ду / прот- }\end{array}$ \\
\hline
\end{tabular}




\begin{tabular}{|c|c|c|c|c|c|c|c|c|c|c|c|c|c|}
\hline $2-8$ & \multicolumn{13}{|r|}{ P, } \\
\hline P: 9 & \multicolumn{13}{|c|}{ 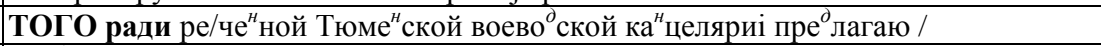 } \\
\hline \begin{tabular}{c|c}
$10--$ \\
26
\end{tabular} & \multicolumn{13}{|c|}{ 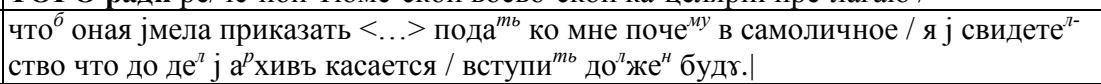 } \\
\hline $\mathrm{D}$ & \multicolumn{13}{|c|}{ марта «9» дня 1766 го ${ }^{\text {dy* }}$} \\
\hline $\mathrm{S}_{\mathrm{p}}$ & \multicolumn{13}{|c|}{ Василеи Рыкачевъ } \\
\hline $3 / 3$ & \multicolumn{13}{|c|}{$\begin{array}{r}\text { Предложение, } 1788 \text { г. [8. С. 359-360] } \\
\end{array}$} \\
\hline $\begin{array}{c}\text { Рекви- } \\
\text { зит }\end{array}$ & \multicolumn{11}{|c|}{ Количество в документе } & \multirow{3}{*}{\multicolumn{2}{|c|}{$\begin{array}{c}\text { «Сила знака»: } \\
\text { кол-во слов / } \\
\text { кол-во знаков }\end{array}$}} \\
\hline \multirow{4}{*}{$\begin{array}{l}\text { Рекви- } \\
\text { зит: } \\
\text { предика } \\
\text { тивная } \\
\text { часть }\end{array}$} & \multirow{3}{*}{ слов } & \multicolumn{4}{|c|}{ знаков всего } & \multicolumn{6}{|c|}{ употреблений } & & \\
\hline & & \multirow{2}{*}{ есть } & \multirow{2}{*}{$\begin{array}{c}\text { могло } \\
\text { бы } \\
\text { быть }\end{array}$} & \multicolumn{2}{|c|}{$\begin{array}{l}\text { из них совпа- } \\
\text { дает по }\end{array}$} & & \multirow{2}{*}{ : } & \multirow{2}{*}{ : } & \multirow[b]{2}{*}{; } & & \multirow{2}{*}{. } & & \\
\hline & & & & месту & $\begin{array}{c}\text { функ- } \\
\text { ции }\end{array}$ & & & & & & & есть & $\begin{array}{c}\text { могло бы } \\
\text { быть }\end{array}$ \\
\hline & ть 352 & $\begin{array}{c}25 \\
(75,8 \%)\end{array}$ & 33 & 20 & 16 & 25 & - & - & - & - & - & 14,08 & $10,67\left(1,3^{\mathrm{K}}\right)$ \\
\hline $\mathrm{S}$ & \multicolumn{13}{|c|}{ Тюменской округи земскаго јсправника / примеръ маіора Угримова, } \\
\hline A & \multicolumn{13}{|c|}{ Тюменскому / нижнему земскому суду, / } \\
\hline $\mathrm{N}$ & \multicolumn{13}{|c|}{ Предложение, / } \\
\hline K: 1 & \multicolumn{13}{|c|}{ До сведения моего дошло, } \\
\hline $2-7$ & \multicolumn{13}{|c|}{ что < ... дро/вамъ чинится гибель, } \\
\hline P: 8 & \multicolumn{13}{|c|}{$\begin{array}{l}\text { того ради во јзбе/жание сего, в Тюменскои нижнои земско }{ }^{u} / \text { суд симъ предла- } \\
\text { гаю учинить следяющее }\end{array}$} \\
\hline $9-25$ & \multicolumn{13}{|c|}{ <... > јметь при волостномъ суде особую / записную тетрать, ${ }^{*}$} \\
\hline $\mathrm{S}_{\mathrm{p}}$ & \multicolumn{13}{|c|}{ Изсправнікъ моіорь / Јванъ Угримо ${ }^{6} *$} \\
\hline $\mathrm{D}$ & Августа & $12^{20}$ дня & 1788 ГС & да, & & & & & & & & & \\
\hline
\end{tabular}

Представленные в табличном варианте предложения содержат 20,8, 24,1 и $75,8 \%$ возможных (с учетом грамматики текста) знаков препинания, при этом в соответствии с формулярным принципом в них использовано $40,28,6$ и $24 \%$ знаков.

Всего в трех документах 33 запятые, две точки, по одной точке с запятой и «полусроке» (.)). Функции знаков часто совпадают с современными: $80,42,9$ и $64 \%$. Мы можем утверждать, что данные документы отличаются достаточно высокой пунктуационной грамотностью.

Коэффициент трудности восприятия текстов с исходным набором знаков составляет $6^{\mathrm{K}}, 4,8^{\mathrm{K}}$ и $1,3^{\mathrm{K}}$.

В начальном блоке представленных в табличном варианте предложений реквизиты имеют последовательность $\mathrm{S}-\mathrm{A}-\mathrm{N}$. Эту формулу находим в 11 из 18 анализируемых документов, формулу N-S-A - в трех. Вариант A-N, без указания отдельным реквизитом субъекта волеизъявления представлен в трех подписанных (имеющих реквизит $\mathrm{S}_{\mathrm{p}}$ ) беловых документах (из них одна копия) и в одном неподписанном черновике.

Таким образом, в 78\% исследованных предложений реквизит $\mathrm{S}$ вербализован и предшествует реквизиту А. Начальный блок завершается знаком препинания (варианты: , / . . .|) в 33,3\% предложений. 
Реквизит $\mathrm{S}$ актуализирован стоящим после него знаком препинания (, / ;) в $28,6 \%$;

реквизит А $(, /$; / . / .|) - в 33,3\%;

реквизит $\mathrm{N}(, /$. $)-16,7 \%$.

Казусная часть текстового блока отграничивается от прагматической знаком препинания (; / , / .) в 72,2\% предложений, при этом в семи случаях из 13 это точка с запятой, на втором месте (пять случаев) - запятая.

Скрепа на границе частей имеется в 88,9\% предложений, из них в 62,5\% в составе скрепы есть анафорическое местоимение со значением, вмещающим содержание казусной части (того ради (4), и для того (3), вследствие того, на что, чего для); в пяти прочих документах прагматическая часть вводится союзом ( $a, u, m o)$.

Прагматическая часть заканчивается знаком препинания в $61 \%$ предложений, при этом в шести случаях из 11 это запятая.

Дата предшествует подписи в 76,5\% предложений, при этом отделяется от подписи знаком (, / : / :| / .|) в четырех документах из 13.

Таким образом, в пунктуационной картине предложений самым важным оказывается, во-первых, разграничение казусной и прагматической части; во-вторых, актуализация посредством предшествующей точки с запятой и местоименной скрепы волеизъявления высшего должностного лица, лексически вводимого личной субъектной формой перформативного глагола предлагаю.

\section{Доношения}

Доношения екатерининской эпохи представлены в архиве двумя типами документов:

1) полностью соответствующие формуляру, рекомендованному Формой о титулах Императрицы Екатерины II от 2 июля 1762 г. № 11.590 [25. С. 7], с апелляцией непосредственно к императрице «Всепресвђтльишая державнъишая великая гостдарыня императрица Екатерина Алез̆ъевна самодержица всероссиіская гдрня всемилостивьишая» [8. С. 512]. Всего в наших материалах 18 подобных документов, в структуре формуляра имеющих также самоназвание «челобитная», из них пять опубликовано [8. C. 519-526, 528];

2) составленные по общему для прочих документов формуляру со свободным лексико-грамматическим наполнением текстов - именно эти документы мы и рассматриваем в настоящей статье. Помимо 18 опубликованных документов [8. С. 67-99], к исследованию привлечено 16 архивных источников [26], всего 34 доношения 1762-1791 гг.; из них одно - в оригинале и в копии.

Три представленных в табл. 6 доношения содержат 53,8, 18 и 77,8\% возможных знаков препинания, при этом в соответствии с формулярным принципом в них использовано 10,5, 20 и 42,9\% знаков. 
Доношения

\begin{tabular}{|c|c|c|c|c|c|c|c|c|c|c|c|c|c|c|}
\hline $1 / 4$ & \multicolumn{14}{|c|}{ Доношение, 1764 г. [8. С. 69-71] } \\
\hline \multicolumn{2}{|c|}{$\begin{array}{c}\text { Рекви- } \\
\text { зит } \\
\end{array}$} & \multicolumn{11}{|c|}{ Количество в документе } & \multirow{3}{*}{\multicolumn{2}{|c|}{$\begin{array}{c}\text { «Сила знака»: } \\
\text { кол-во слов / } \\
\text { кол-во знаков }\end{array}$}} \\
\hline \multirow{4}{*}{\multicolumn{2}{|c|}{$\begin{array}{c}\text { Рекви- } \\
\text { зит: } \\
\text { предика- } \\
\text { тивная } \\
\text { часть }\end{array}$}} & \multirow{3}{*}{ слов } & \multicolumn{4}{|c|}{ знаков всего } & \multicolumn{6}{|c|}{ употреблений } & & \\
\hline & & & \multirow{2}{*}{ есть } & \multirow{2}{*}{$\begin{array}{c}\text { могло } \\
\text { бы } \\
\text { быть }\end{array}$} & \multicolumn{2}{|c|}{$\begin{array}{c}\text { из них } \\
\text { совпадает по }\end{array}$} & \multirow[b]{2}{*}{, } & \multirow{2}{*}{$:$} & \multirow{2}{*}{\multicolumn{2}{|c|}{$: \mid$}} & & \multirow[b]{2}{*}{.} & & \\
\hline & & & & & месту & \begin{tabular}{|c|} 
функ- \\
ции \\
\end{tabular} & & & & & & & есть & $\begin{array}{c}\text { могло бы } \\
\text { быть }\end{array}$ \\
\hline & & 391 & $\begin{array}{c}19 \\
(52,8 \%) \\
\end{array}$ & 36 & 10 & 1 & \multicolumn{2}{|c|}{\begin{tabular}{l|l}
8 & 11 \\
\end{tabular}} & \multicolumn{2}{|c|}{$-1-$} & \multicolumn{2}{|c|}{$-1-$} & 20,58 & $10,86(1,9)^{\mathrm{K}}$ \\
\hline A & $\begin{array}{l}\text { Вель } \\
\text { ском }\end{array}$ & $\begin{array}{l}\text { lикомг } \\
\text { мr / }\end{array}$ & гддня пре & еосщенн? & Ђйшемү & аvл & & & & & & & r & Сибир- \\
\hline $\mathrm{S}$ & $\mathrm{Tp}^{o} \mathrm{~L}$ & цкаго & Рафайлов & ва мнүтря & $\mathrm{o}^{m}$ архи & мандрит & $\mathrm{ra} /$ & Нек & ттар & ія: / & & & & \\
\hline $\mathrm{N}$ & поко & орнъй & шее доно & шеніе / & & & & & & & & & & \\
\hline $\mathrm{K}: 1$ & $\begin{array}{l}\text { Сего } \\
\text { Тебе }\end{array}$ & $\begin{array}{l}\text { о апрь } \\
\text { еняцкс }\end{array}$ & $\begin{array}{l}\text { эля } 21 \text { дня } \\
\text { ой слободІ }\end{array}$ & $\begin{array}{l}\text { в в подан } \\
\text { ыы о }{ }^{m} \text { кре }\end{array}$ & $\begin{array}{l}\text { Іномъ мн } \\
\text { естьянин }\end{array}$ & $\begin{array}{l}\text { ib јмено/ } \\
\text { a Фекли }\end{array}$ & & $\begin{array}{l}\mathrm{HHOM} \\
/ \text { Па }\end{array}$ & & $\begin{array}{l}\text { Ялгт } \\
\text { гин } \\
\end{array}$ & $\begin{array}{l}\text { ropo } \\
\text { bxъ }\end{array}$ & $\mathrm{O}^{\bar{\sigma}} \mathrm{g}$ & аго ди & $\begin{array}{l}\text { стрикта / } \\
\text { и написано, }\end{array}$ \\
\hline $2-20$ & сего & де 17 & 767 го ${ }^{\partial y} / \mathrm{B}$ & въ шестя & үю недЂл & лю Вели & каг & о по & ста & $<$. &.$>0$ & THЯ & Іли: & \\
\hline 21 & $\begin{array}{l}\text { кото } \\
\text { Прес }\end{array}$ & $\begin{array}{l}\text { орое п } \\
\text { осёщен }\end{array}$ & $\begin{array}{l}\text { Іо линное } \\
\text { нств / на }\end{array}$ & $\begin{array}{l}\mathbf{0}^{\sigma} \mathbf{я в л е} \\
\text { благора }\end{array}$ & $\begin{array}{l}\text { нiе при с } \\
3^{3} \text { смотрег }\end{array}$ & $\begin{array}{l}\text { семъ все } \\
\text { ніе прио }\end{array}$ & $\begin{array}{ll}\text { пок } \\
\text { бщс }\end{array}$ & $\begin{array}{l}\text { корн } \\
\text { аетс }\end{array}$ & 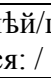 & & 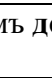 & & ошеніи & Вашемr \\
\hline $\begin{array}{l}\mathrm{P}: \\
22\end{array}$ & $\begin{array}{l}\text { О че } \\
\text { доне }\end{array}$ & емъ B & $\begin{array}{l}\text { Зашемr Пр } \\
\text { іемъ на бл }\end{array}$ & $\begin{array}{l}\text { реосщен } \\
\text { лагоразс }\end{array}$ & $\begin{array}{l}\text { нствя: вы } \\
\text { смотрені }\end{array}$ & $\begin{array}{l}\text { Iшепре/д } \\
\text { е ј предс }\end{array}$ & & & $\begin{array}{l}\text { Hом? } \\
\text { етъс }\end{array}$ & & & & покор & ньйшимъ / \\
\hline $\mathrm{D}$ & апр1 & Бля 26 & 5 дня 1764 & 4 года & & & & & & & & & & \\
\hline $\mathrm{S}_{\mathrm{p}}$ & Ваш & шего П & Іреосищенс & ства / все & егдашни & ии посля & ШHL & икъ* & $* / \mathrm{A}$ & Apxi & Haviat & пдр & $\mathrm{bH}$ & рій \\
\hline $2 / 5$ & & & & & оношени & иe, 1768 & г. [ & $8 . \mathrm{C}$ & .74 & $4-77$ & & & & \\
\hline $\begin{array}{r}\text { Рекв } \\
\text { зит }\end{array}$ & & & & Колич & чество в & докуме & нте & & & & & & «Си & лла знака»: \\
\hline & & & & знаков & всего & & & упо & трес & блең & ний & & кол & І-во слов / \\
\hline $\begin{array}{r}\text { Рекв } \\
\text { зит }\end{array}$ & & слов & & могло & $\begin{array}{r}\text { из н } \\
\text { совпад }\end{array}$ & $\begin{array}{l}\text { них } \\
\text { қает по }\end{array}$ & & & & & & & кол- & -во знаков \\
\hline $\begin{array}{l}\text { преди } \\
\text { тивн }\end{array}$ & $\begin{array}{l}\text { ика- } \\
\text { ная }\end{array}$ & & есть & $\begin{array}{c}\text { бы } \\
\text { быть }\end{array}$ & \begin{tabular}{|l|} 
месту \\
\end{tabular} & \begin{tabular}{|c|} 
функ- \\
ции \\
\end{tabular} & , & $:$ & : & ; & . & $\cdot \mid$ & есть & $\begin{array}{c}\begin{array}{c}\text { могло бы } \\
\text { быть }\end{array} \\
\end{array}$ \\
\hline част & & 727 & $\begin{array}{c}20 \\
(18 \%) \\
\end{array}$ & 111 & 17 & 15 & 20 & - & - & - & - & - & 36,35 & $6,55(5,5)^{\mathrm{K}}$ \\
\hline $\mathrm{A}$ & $\mathrm{B} \mathrm{Tr}$ & юменс & скүю воев & зодскүю & канцеля & рію, / & & & & & & & & \\
\hline$S$ & $\mathrm{o}^{m} \mathrm{y}$ & сстниц & цынского & гправит & еля вахм & иистра / & Бри & Iмер & & & & & & \\
\hline $\mathrm{N}$ & доно & ошені & & & & & & & & & & & & \\
\hline K: 1 & $\begin{array}{l}\text { Сего } \\
\text { КочІ } \\
\text { мне } \\
\end{array}$ & $\begin{array}{l}\text { О сент } \\
\text { Iюровь } \\
\text { / имян } \\
\end{array}$ & $\begin{array}{l}\text { сября } 24^{2} \text { ч } \\
\text { ь Прокопе } \\
\text { нованном } \\
\end{array}$ & $\begin{array}{l}\text { числа зде } \\
\text { еи Козми } \\
\text { ия жалоб }\end{array}$ & $\begin{array}{l}\text { цешнеи У } \\
\text { инъ Дань } \\
\text { бу такүю }\end{array}$ & $\begin{array}{l}\text { сть/ниц } \\
\text { ило Коч } \\
\end{array}$ & & & $\begin{array}{l}\text { й сл } \\
\text { Ив } \\
\end{array}$ & $\begin{array}{l}060, \\
\text { занъ } \\
\end{array}$ & $\begin{array}{l}\text { ды } \\
\text { Окс } \\
\end{array}$ & сен & $\begin{array}{l}\text { стьяне } \\
\text { овъ пр } \\
\end{array}$ & $\begin{array}{l}\text { Никифо }^{p} / \\
\text { иносили ко } \\
\end{array}$ \\
\hline \begin{tabular}{|l|l}
$2-56$ \\
\end{tabular} & $\begin{array}{l}\text { что } \\
\text { ревъ }\end{array}$ & $\begin{array}{l}<\ldots>\text { j } \\
\text { b/ про }\end{array}$ & $\begin{array}{l}\text { ј просили } \\
\text { отивъ по }{ }^{\partial} \text {. }\end{array}$ & $\begin{array}{l}\text { I чтобъ < } \\
\text { рядной и }\end{array}$ & $\begin{array}{l}\ldots . .>\mathrm{o}^{m} \mathrm{p} \\
\text { ихъ запис }\end{array}$ & $\begin{array}{l}\text { работы / } \\
\text { си налаг }\end{array}$ & $\begin{array}{l}\text { yв } \\
\text { гаeт }\end{array}$ & $\begin{array}{l}\text { олит } \\
\text { гъ на }\end{array}$ & $\begin{array}{l}\text { ть д } \\
\text { а ни } \\
\end{array}$ & $\begin{array}{l}\text { a и } \\
\text { ххъ } 1\end{array}$ & $\begin{array}{l}\text { крол } \\
\text { рабо }\end{array}$ & $\begin{array}{l}\text { ме } \\
\text { оту }\end{array}$ & $\begin{array}{l}\text { де тогс } \\
\text { јзлиш }\end{array}$ & $\begin{array}{l}\text { тотъ Зуба- } \\
\text { ную, }\end{array}$ \\
\hline $\begin{array}{l}P: \\
57\end{array}$ & $\begin{array}{l}\text { Tоге } \\
\text { корн }\end{array}$ & $\begin{array}{l}\text { о ради } \\
\text { но / пр }\end{array}$ & $\begin{array}{l}\text { и о вышеп } \\
\text { рошя }\end{array}$ & писаннол & мъ Тюме & енской / & & евод & дско & ой кс & & & рій дою & ношү и по- \\
\hline \begin{tabular}{|c|}
$58-$ \\
67 \\
\end{tabular} & $\begin{array}{l}\text { дабь } \\
\text { милс }\end{array}$ & $\begin{array}{l}\text { ы собл } \\
\text { оостив? }\end{array}$ & $\begin{array}{l}\text { паговолен } \\
\text { үю / резо }\end{array}$ & $\begin{array}{l}\text { то было } \\
\text { люцію, }\end{array}$ & $\langle\ldots\rangle \mathrm{o}^{m}$ & работы & & & & & & & томь & учинить \\
\hline $\mathrm{D}$ & сент & тября 2 & $25^{2}$ дня 17 & 768 года, & & & & & & & & & & \\
\hline$S_{p}$ & Упр & оавите. & ль вахтме & естеръ $\Phi$ & едорь Бा & римерь & & & & & & & & \\
\hline $3 / 6$ & & & & & оноше & e, 1774 & г. [ & & . & 2 & & & & \\
\hline
\end{tabular}




\begin{tabular}{|c|c|c|c|c|c|c|c|c|c|c|c|c|c|c|}
\hline \multicolumn{2}{|c|}{$\begin{array}{c}\text { Рекви- } \\
\text { зит } \\
\end{array}$} & \multicolumn{11}{|c|}{ Количество в документе } & \multirow{3}{*}{\multicolumn{2}{|c|}{$\begin{array}{c}\text { «Сила знака»: } \\
\text { кол-во слов / кол- } \\
\text { во знаков }\end{array}$}} \\
\hline \multirow{4}{*}{\multicolumn{2}{|c|}{$\begin{array}{c}\text { Рекви- } \\
\text { зит: } \\
\text { предика- } \\
\text { тивная } \\
\text { часть }\end{array}$}} & \multirow{3}{*}{ - слов } & \multicolumn{4}{|c|}{ знаков всего } & \multicolumn{6}{|c|}{ употреблений } & & \\
\hline & & & \multirow{2}{*}{ есть } & \multirow{2}{*}{$\begin{array}{c}\text { могло } \\
\text { бы } \\
\text { быть }\end{array}$} & \multicolumn{2}{|c|}{$\begin{array}{c}\text { из них } \\
\text { совпадает по }\end{array}$} & \multirow[b]{2}{*}{, } & \multirow{2}{*}{ : } & \multirow{2}{*}{$: \mid$} & \multirow{2}{*}{; } & & \multirow{2}{*}{.1} & & \\
\hline & & & & & месту & $\begin{array}{c}\text { функ- } \\
\text { ции }\end{array}$ & & & & & & & есть & $\begin{array}{c}\text { могло бы } \\
\text { быть }\end{array}$ \\
\hline & & 171 & $\begin{array}{c}7 \\
(77,8 \%) \\
\end{array}$ & 9 & 5 & 3 & 3 & 3 & - & 1 & - & - & 24,43 & $19(1,3)^{\mathrm{K}}$ \\
\hline $\mathrm{A}$ & B 1 & Тюмег & нскүю кол & ендансі & ю кан & елярию & & & & & & & & \\
\hline $\mathrm{S}$ & Тю & менск & кои гарни & зонной / & команд & салда & $\mathrm{a} \mathrm{N}$ & Мих: & aи1J1 & $a / 1$ & aMn & ИHC & кого: / & \\
\hline $\mathrm{N}$ & до1 & ноше & ние / & & & & & & & & & & & \\
\hline $\begin{array}{l}\mathrm{K}: \\
1-5\end{array}$ & $\begin{array}{l}\mathrm{Yp} \\
\mathrm{Cu} \\
<. .\end{array}$ & $\begin{array}{l}\text { ождег } \\
\text { обирь } \\
\text {.> жи }\end{array}$ & $\begin{array}{l}\text { нецъ я им } \\
\text { где по / гс } \\
\text { тельство }\end{array}$ & $\begin{array}{l}\text { енованн } \\
\text { роду Тң } \\
\text { иметь Р }\end{array}$ & $\begin{array}{l}\text { ми полс } \\
\text { мени и } \\
\text { ссіиско }\end{array}$ & $\begin{array}{l}\text { ои наці } \\
\text { опреде } \\
\text { й / Имп }\end{array}$ & & $\begin{array}{l}\ldots> \\
\ldots \text { В с } \\
\text { І ЗДе }\end{array}$ & & & $\begin{array}{l}\text { वвож } \\
\text { : а } 1 \\
\text { иби }\end{array}$ & & $\begin{array}{l}\text { Нъ чре } \\
\text { / я им }\end{array}$ & $\begin{array}{l}\text { ь Россію в } \\
\text { ю желаніе }\end{array}$ \\
\hline P: 6 & и д & цля то & го Тю/ме & Нскүю к & рмендан & скүю ка & НЦС & еляр & ию & си & / Пс & око & рнеиш & прошя \\
\hline $7-8$ & чTO & объ $<$. & ..> уволи & ть на со & ственн & е мое п & pon & итал & ние & & & & & \\
\hline $\mathrm{S}_{\mathrm{p}}$ & $\begin{array}{l}\mathrm{K} \mathrm{c} \\
\mathrm{cKO}\end{array}$ & $\begin{array}{l}\text { сему д } \\
\text { о каза }\end{array}$ & $\begin{array}{l}\text { цоношени } \\
\text { чеи / пяти }\end{array}$ & $\begin{array}{l}\text { г вмест } \\
\text { цеся }{ }^{m} \text { ни }\end{array}$ & $\begin{array}{l}\mathrm{ca}^{\pi} \text { дат } \\
\text { Ђ Петр }\end{array}$ & $\begin{array}{l}\text { а Михаা } \\
\text { в Старк }\end{array}$ & ла & $\begin{array}{l}\text { / Ка } \\
\text { рук }\end{array}$ & $\mathrm{MI}$ & & $\begin{array}{l}\text { ГО } \\
\text { IOЖ }\end{array}$ & & $\begin{array}{l}\text { про36 } \\
\text { Ђ* }\end{array}$ & березав- \\
\hline $\mathrm{D}$ & Ию & оня 10 & ${ }^{20}$ дня 17? & 74 году & & & & & & & & & & \\
\hline
\end{tabular}

Всего в трех документах 31 запятая, 14 двоеточий, одна точка с запятой. Функции знаков в разной мере совпадают с современными: 5,3, 75 и 42,9\%. Таким образом, данные доношения демонстрируют различную степень пунктуационной грамотности субъектов письма.

Коэффициент трудности восприятия доношений с исходным набором знаков составляет $1,9^{\mathrm{K}}, 5,5^{\mathrm{K}}$ и $1,3^{\mathrm{K}}$, что несколько меньше, чем при восприятии представленных выше предложений.

Во всех 34 исследуемых в формулярном аспекте доношениях выдержана последовательность реквизитов $\mathrm{A}-\mathrm{S}-\mathrm{N}$, отличающаяся от формулы предложений.

Реквизит А актуализирован посредством знака препинания (, / ; / . / .|) после него в 14,3\% доношений, реквизит $\mathrm{S}$ знаком $(, /$ : $)$ после него в $17,1 \%$ доношений, реквизит $\mathrm{N}$, т.е. абсолютный конец начального блока формуляра, - знаком (, / :) в 8,6\% случаев.

Конец казусной части отмечен знаком в 48,6\% анализируемых доношений, при этом чаще (шесть знаков из 17) - точкой с запятой, затем следуют запятая (5) и двоеточие (4); по одному употреблению точки и сроки.

Скрепа вводит прагматическую часть в 91,4\% доношений, при этом скрепу с анафорическим местоимением (того ради (15), и для того (4), чего для (2), о чем (2)) находим в 78,1\% текстов, союз (u (5), $a$, то) на границе частей - в 21,9\% анализируемых доношений. Конструкция, синтаксически главенствующая в прагматической части, представлена основными вариантами представляю / -ет / -ется (на рассмотрение / благорассмотрение) / доношу / с вербализацией только одной коммуникативной цели официального сообщения, доведения информации до сведения вышестоящего коммуниканта; значительно реже - с двумя, с «подключением» личного интереса адресанта: объявляю и прошу. 
Конец прагматической части заканчивается знаком в 40\% случаев, при этом чаще - срокой (6), запятой (5), а также двоеточием (2) и точкой с запятой (1). Следующим в 57,1\% доношений следует реквизит «Подпись» (только в двух случаях отграниченный от последующей даты знаком сроки или запятой), в 42,9\% - реквизит «Дата» (в этом случае знак запятой, точки или сроки находим в пяти документах).

Таким образом, формулярная граница казусной и прагматической части в доношениях воспринимается субъектом письма также как наиболее значимая среди прочих реквизитов формуляра и потому нуждающаяся в актуализации посредством знака препинания, хотя в сравнении с предложениями такая актуализация происходит почти в 1,5 раза реже.

Сравнение архивных оригинала и копии покорнейшего доношения [27] от 6 марта 1788 г., поданного к Тюменским городническим делам тюменскими крестьянами Михайлой и Алексеем Гребешковыми, о нарушении договора о покупке сала показало, что составитель копии переписал текст с пунктуацией, лишь частично совпадающей с пунктуацией оригинала. В частности, всего в оригинале 21 знак (.| / : / , / .), в копии - 13 (из них 12 запятых и одна точка с запятой на границе казусной и прагматической частей); при этом из семи потенциальных формулярных позиций для знака препинания оригинал и копия совпадают только в двух, а именно в отсутствие знака при реквизитах $\mathrm{S}$ и $\mathrm{N}$. Прочие пять позиций соотносятся следующим образом (первым представим оригинал): (А./А), (К/К;), (P/P,), $\left(\mathrm{S}_{\mathrm{p}} / \mathrm{S}_{\mathrm{p}},\right)(\mathrm{D} / \mathrm{D}$,$) . В реквизите «Текст» совпадают по месту употребления$ шесть знаков, при этом все «полусроки» (.|) оригинала (наиболее частотного в оригинале знака - 11 из 21) заменены запятыми копии. Таким образом, для составителя копии более важным оказалось разграничить реквизиты формуляра, чем посредством знаков препинания выделить смысловые отношения, отражающие ситуацию в реальной действительности.

\section{Объявления}

Всего в анализируемом материале 26 опубликованных объявлений 1763-1793 гг. [8. С. 210-244] и 46 архивных источников 1767-1790 гг. [28], итого 72 документа.

Представленные в табл. 7 объявления содержат принципиально меньше, по сравнению с предложениями и доношениями, знаков препинания: 44,4, 20 и 5,9\% от возможного их количества, при этом в соответствии с формулярным принципом использованы практически все знаки - 62,5, 100 и $100 \%$.

Всего в трех объявлениях набор знаков разнообразнее (5), чем в предложениях (4) и доношениях (3), хотя общее их количество значительно меньше: четыре запятых, два двоеточия, две точки с запятой и по одной сроке и точке (всего 10). 


\section{Объявления}

\begin{tabular}{|c|c|c|c|c|c|c|c|c|c|c|c|c|c|}
\hline $1 / 7$ & \multicolumn{13}{|c|}{ Объявление, 1787 г. [8. С. 215, 216] } \\
\hline $\begin{array}{c}\text { Рекви- } \\
\text { зит }\end{array}$ & \multicolumn{11}{|c|}{ Количество в документе } & \multirow{3}{*}{\multicolumn{2}{|c|}{$\begin{array}{l}\text { «Сила знака»: } \\
\text { кол-во слов / } \\
\text { кол-во знаков }\end{array}$}} \\
\hline \multirow{4}{*}{$\begin{array}{l}\text { Рекви- } \\
\text { зит: } \\
\text { предика- } \\
\text { тивная } \\
\text { часть }\end{array}$} & \multirow{3}{*}{ слов } & \multicolumn{4}{|c|}{ знаков всего } & \multicolumn{6}{|c|}{ употреблений } & & \\
\hline & & \multirow{2}{*}{ есть } & \multirow{2}{*}{$\begin{array}{c}\text { могло } \\
\text { бы } \\
\text { быть }\end{array}$} & \multicolumn{2}{|c|}{$\begin{array}{c}\text { из них } \\
\text { совпадает по }\end{array}$} & \multirow[b]{2}{*}{, } & \multirow[b]{2}{*}{ : } & \multirow{2}{*}{$: \mid$} & \multirow[b]{2}{*}{; } & \multirow{2}{*}{\multicolumn{2}{|c|}{ - }} & & \\
\hline & & & & месту & $\begin{array}{c}\text { функ- } \\
\text { ции }\end{array}$ & & & & & &. & есть & $\begin{array}{l}\text { могло бы } \\
\text { быть }\end{array}$ \\
\hline & 162 & $\begin{array}{c}8 \\
(44,4 \%)\end{array}$ & 18 & 5 & 1 & 4 & 2 & - & 1 & 1 & - & 20,25 & $9(2,3)^{\mathrm{K}}$ \\
\hline \multirow{3}{*}{\multicolumn{14}{|c|}{\begin{tabular}{l|l}
$\mathrm{A}$ & К Тюменскимъ городническимъ деламъ / \\
$\mathrm{S}$ & Тюменского нижнего земского суда ка ${ }^{H}$ це/ляриста Луки Милкъева, / \\
$\mathrm{N}$ & объявление. /
\end{tabular}}} \\
\hline & & & & & & & & & & & & & \\
\hline & & & & & & & & & & & & & \\
\hline & & & & & & & & & & & \\
\hline & \multirow{2}{*}{\multicolumn{13}{|c|}{$\begin{array}{l}\text { ТОГО РАДИ Тюменскимъ / городническимъ деламъ симъ о }{ }^{\circ} \text { яляяю / и прошу } \\
<\text { <..> изследовать, и мне доставить / законное удоволствие: }\end{array}$}} \\
\hline $14-17$ & & & & & & & & & & & & & \\
\hline \begin{tabular}{l|l}
$\mathrm{D}$ & $\mathrm{I}$ \\
\end{tabular} & \multicolumn{13}{|c|}{ марта 3 / дня 1787 года; } \\
\hline $\mathrm{S}_{\mathrm{p}}$ & \multirow{2}{*}{\multicolumn{13}{|c|}{ 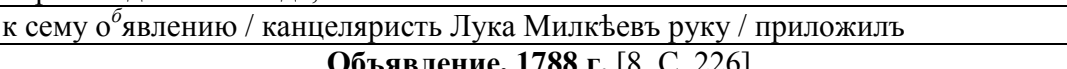 }} \\
\hline $2 / 8$ & & & & & & & & & & & & & \\
\hline $\begin{array}{l}\text { Рекви- } \\
\text { зит }\end{array}$ & \multicolumn{11}{|c|}{ Количество в документе } & $« \mathrm{C}$ & знака»: \\
\hline & & & знаков & всего & & & упо & трес & блен & ний & & кол- & во слов / \\
\hline зит: & слов & & могло & $\begin{array}{r}\text { из } \mathrm{I} \\
\text { совпад }\end{array}$ & $\begin{array}{l}\text { Іих } \\
\text { ает по }\end{array}$ & & & & & & & кол- & зо знаков \\
\hline $\begin{aligned} \text { предика } \\
\text { тивная } \\
\text { часть }\end{aligned}$ & & есть & $\begin{array}{c}\text { бы } \\
\text { быть }\end{array}$ & месту & $\begin{array}{l}\text { функ- } \\
\text { ции }\end{array}$ & , & $:$ & $: \mid$ & ; & - & .1 & есть & $\begin{array}{c}\text { могло бы } \\
\text { быть }\end{array}$ \\
\hline & 81 & $1(20 \%)$ & 5 & - & - & - & - & 1 & - & - & - & 81 & $16,2(5)^{\mathrm{K}}$ \\
\hline $\mathrm{A}$ & Тюме & енскимъ Г & ороднич & ееским & деламъ / & & & & & & & & \\
\hline $\mathrm{S}$ & ${ }^{n}$ тюІ & енскаго & рестьяни & ина / Mc & ына М & Іака & apos & $a: \mid$ & & & & & \\
\hline $\mathrm{N}$ & явлег & ние & & & & & & & & & & & \\
\hline K: $1-4$ & его ге & ннаря 20 & дня $<\ldots>$ & корову & свою $<$. & $\ldots>$ & исг & аль & и н & $\mathrm{Ia}^{m} \mathrm{~T}$ & и/ & не мог & \\
\hline P: 5 & ого ра & ади Тюме & нски/Мъ & городни & ческимъ & б де & ела ${ }^{\mu}$ & $\mathrm{O}^{6} \mathrm{gl}$ & ВЛЯН & $0^{*}$ & & & \\
\hline$S_{p}$ & сему & $\begin{array}{l}\text { о }^{6} \text { явленин } \\
\text { Іобозеро }\end{array}$ & $\begin{array}{l}\text { о вместс } \\
\text { руку прг }\end{array}$ & $\begin{array}{l}\text { кресть } \\
\text { иложиль }\end{array}$ & нина / N & & & & & & & пр & оои казакъ \\
\hline $\mathrm{D}$ & енварs & я 22 дня / & 1788 год & & & & & & & & & & \\
\hline $3 / 9$ & & & Объ & явлени & $1791 \Gamma$ & $\cdot[8$ & 3. C. & 241 &, 24 & & & & \\
\hline $\begin{array}{c}\text { Рекви- } \\
\text { зит }\end{array}$ & & & Коли & чество в & докумен & нте & & & & & & «Си. & а знака»: \\
\hline & & & знаков & всего & & & упо & трес & блен & ний & & кол-во & слов / кол- \\
\hline $\begin{array}{l}\text { Рекви- } \\
\text { зит: }\end{array}$ & слов & & могло & $\begin{array}{r}\text { из них } \\
\text { дает }\end{array}$ & $\begin{array}{l}\text { овпа- } \\
\text { то }\end{array}$ & & & & & & & & знаков \\
\hline $\begin{array}{r}\text { предика } \\
\text { тивная }\end{array}$ & & есть & $\begin{array}{c}\text { бы } \\
\text { быть }\end{array}$ & месту & $\begin{array}{c}\text { функ- } \\
\text { ции } \\
\end{array}$ & , & : & : & ; & - & .1 & есть & $\begin{array}{c}\text { могло бы } \\
\text { быть }\end{array}$ \\
\hline & 238 & $1(5,9 \%)$ & 17 & - & - & - & - & - & 1 & - & - & 238 & $14(17)^{\mathrm{K}}$ \\
\hline A & Тюмь & нскои гор & одовои & магистр & $\mathrm{Tъ} ; /$ & & & & & & & & \\
\hline S & $\begin{array}{l}\text { жН } \\
\text { / В }\end{array}$ & $\begin{array}{l}\text { го тюмђ } \\
\text { рђкруты }\end{array}$ & $\begin{array}{l}\text { ского цњ } \\
\text { Бьдора I }\end{array}$ & $\begin{array}{l}\text { ховаго в } \\
\text { Шмаков }\end{array}$ & ныне & & & & & & & ои не & оръ приня- \\
\hline
\end{tabular}




\begin{tabular}{|c|c|}
\hline $\mathrm{N}$ & объявление \\
\hline K: & $\begin{array}{l}\text { Какъ }<\ldots>\text { дингъ }<\ldots>\text { по нъблагопо/лучному торгг выплатить никакъ было / мнъ } \\
\text { нъможно <...> о томъ свођмъ / одолженій и объявить Тюмънскому городо/вому } \\
\text { магистрату нъ удалось }\end{array}$ \\
\hline $\mathrm{P}: 5$ & того ради / симъ покорнеише прош \\
\hline $6-9$ & $\begin{array}{l}\text { вышظписанное / мое одолжение кръдиторамъ приказа }{ }^{m b} \text { / заплатить тьмъ за кого } \\
\text { я по нъочереди / отданъ в рекруты <...> }\end{array}$ \\
\hline $\mathrm{D}$ & марта 9 дня / 1791 года * \\
\hline $\mathrm{S}_{\mathrm{p}}$ & $\begin{array}{l}\text { К сему обьевлению леибъ гвардии / Семоновскаго полку рекруть Федоръ Шма- } \\
\text { ков / руку приложиль }\end{array}$ \\
\hline
\end{tabular}

По функции совпал с современным употреблением лишь один знак. Таким образом, привлеченные к анализу объявления, несмотря на то, что в их основе лежит устная речь просителей, т.е. мог бы быть значимым интонационный принцип оформления письменного текста, демонстрируют преимущественно формулярный принцип, что может быть связано в большей степени с пунктуационной выучкой субъекта письма (см. объявление 1/7, написанное самим просителем - профессиональным субъектом письма, канцеляристом Лукой Милкеевым, в котором пунктуационно отмечены пять реквизитов и есть три знака - в соответствии с интонационным принципом, грамматически не поддержанным).

Показатели коэффициента трудности восприятия объявлений имеют больший разброс: $2,3^{\mathrm{K}}, 5^{\mathrm{K}}$ и $17^{\mathrm{K}}$, что может быть обусловлено индивидуальными пунктуационными характеристиками субъектов письма.

Этот вывод косвенно подтверждается, например, тем, что единая для 70 объявлений формула начального протокола A-S-N нарушена вставкой в него реквизита «Дата» в двух объявлениях, составленных в связи с одним и тем же инцидентом и, судя по почерку, одним и тем же субъектом письма: A-D-S-N [8. C. 231-236].

Во всех 72 объявлениях реквизиты формуляра актуализированы знаком препинания значительно реже, чем в предложениях и доношениях, а именно:

$\mathrm{S}(, /: \mid / ;)-9,7 \%$;

A (;) - 1,4\% (см. пример 3/9);

$\mathrm{N}(, /: /)-5,.6 \%$;

$\mathrm{K}(, /: /: \mid / ; /)-.25 \%$;

$\mathrm{P}(, /: /:|/ ; / . /|)-22,.2 \%$;

$\mathrm{D}(: /: \mid / ; /)-6,.9 \%$.

Как видим, знаки препинания в объявлениях в основном сосредоточены в текстовом блоке: на границе казусной и прагматической частей (хотя и в 1,9 раза реже, чем в доношениях) и в конце реквизита «Текст». Скрепа на границе казусной и прагматической частей имеется в $97,2 \%$ объявлений, при этом набор скреп так же разнообразен (9 вариантов), как и в предложениях (8) и доношениях (9). Наиболее употребительным остается местоименный вариант того ради (45), но значимым оказывается и редкий в документах других жанров вариант о чем (15). Единичны варианты $u$ для того, и об оном, чего ради, для чего, в чем, и, о том. 
В половине объявлений скрепа вводит глагольное сочетание, называющее две интенции адресанта - информирования и волеизъявления: объявляю и прошу (см. пример 1/7) или объявя прошу. В $36 \%$ объявлений выражена только интенция сообщения (объявляю; единично: сообщаю, доношу), пример 2/8; в 14\% - вербализована только интенция волеизъявления (прошу), пример 3/9.

\section{Промемории}

К исследованию привлечено 15 опубликованных промеморий 1762 1780 гг. [8. С. 367-386].

В трех промемориях, представленных в табл. 8, в общей сложности девять знаков препинания: ведущим оказывается точка с запятой (6), есть также две сроки и одно двоеточие. Самая «богатая» на знаки - промемория 2/11, в которой использовано 63,6\% возможных, судя по грамматической структуре текста, знаков препинания, причем два совпали по синтаксической функции. В ней два из трех реквизитов начального протокола актуализированы (разными) знаками препинания. В отличие от двух других документ имеет невысокий коэффициент трудности $1,6^{\mathrm{K}}$, в прочих он равен или приближается к максимальному показателю для всех 12 проанализированных таким образом документов четырех жанров $-21^{\mathrm{K}}$ (при отсутствии знаков препинания в тексте) и $10^{\mathrm{K}}$ (при наличии $10 \%$ требуемых грамматической структурой текста знаков).

Формуляр промеморий неизменен и имеет структуру $\mathrm{N}-\mathrm{S}-\mathrm{A}-\mathrm{K}-\mathrm{P}-\mathrm{D}-$ $\mathrm{S}_{\mathrm{p}}$. C учетом частотности знака препинания для 15 проанализированных документов получаем вариант: $\mathrm{N}(1)-\mathrm{S}(1)-\mathrm{A}(3)-\mathrm{K}(8)-\mathrm{P}(2)-\mathrm{D}(4)-\mathrm{S}_{\mathrm{p}}$. Как видим, чаще всего знак препинания (, / : / :| / ;) стоит в конце казусной части. Отсутствие скрепы наблюдаем в 20\% промеморий; при наличии скрепы фиксируем восемь её вариантов, преимущественно того ради (4), а также и для того, а потому, для чего, на что, и, о том, и о том.

Т а б ли ц а 8

\section{Промемории}

\begin{tabular}{|c|c|c|c|c|c|c|c|c|c|c|c|c|c|c|}
\hline $\mathbf{1 / 1 0}$ & & & & Про & иемори & , 1762 & $\Gamma .[$ & $8 . \mathrm{C}$ & .36 & 3 & & & & \\
\hline $\begin{array}{r}\text { Рекв1 } \\
\text { зит }\end{array}$ & & & & Коли & гество в & докуме & HTe & & & & & & $\ll \mathrm{Cl}_{2}$ & ла знака»: \\
\hline & & & & знаков & всего & & & упо & тре & бле & ний & & кол-в & слов / кол- \\
\hline $\begin{array}{r}\text { Рекв } \\
\text { зит: }\end{array}$ & & слов & & могло & $\begin{array}{r}\text { из них } \\
\text { дае }\end{array}$ & $\begin{array}{l}\text { совпа- } \\
\text { по }\end{array}$ & & & & & & & & знаков \\
\hline преди & & & есть & $\begin{array}{c}\text { оы } \\
\text { быть }\end{array}$ & месту & $\begin{array}{c}\text { функ- } \\
\text { ции }\end{array}$ & , & : & $: \mid$ & ; & - & $\cdot \mid$ & есть & $\begin{array}{c}\text { могло бы } \\
\text { быть }\end{array}$ \\
\hline & & 275 & - & 21 & - & - & - & - & - & - & - & - & 275 & $13,09(21)^{\mathrm{K}}$ \\
\hline $\mathrm{N}$ & III & омем & рия / & & & & & & & & & & & \\
\hline $\mathrm{S}$ & & Тюме & ского & агистрат & & & & & & & & & & \\
\hline A & & ююмен & күю / $\mathrm{E}$ & ево ${ }^{\delta}$ скүн & канце & ярию & & & & & & & & \\
\hline K: 1 & & $\begin{array}{l}\text { неже п } \\
\text { едо }{ }^{p} \text { Кс } \\
\text { и четв }\end{array}$ & $\begin{array}{l}\text { оданнь } \\
\text { ншинъ } \\
\text { ртины }\end{array}$ & $\begin{array}{l}\text { / сюда I } \\
\text { lаречнои } \\
\text { едра }\end{array}$ & $\begin{array}{l}\text { енваря } \\
\text { / Ивант }\end{array}$ & $\begin{array}{l}5 \text { дня } 7 \\
\text { Белски }\end{array}$ & & & & & & & $\begin{array}{l}\text { дворе } \\
\text { ставля }\end{array}$ & $\begin{array}{l}\text { выборнои } \\
\text { g <..> вет- }\end{array}$ \\
\hline
\end{tabular}




\begin{tabular}{|c|c|}
\hline $2-7$ & на кое $<\ldots>$ зделана $<\ldots>$ другая чевертина $<\ldots>$ \\
\hline$P: 8$ & $\begin{array}{l}\text { ТОГО ради по указу его / јмператорскаго величества в Тюме } \text { ско }^{h} \text { магистрате } \\
\text { определено }\end{array}$ \\
\hline $9-13$ & 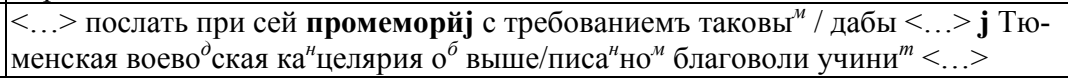 \\
\hline $\mathrm{D}$ & јюля 5 дня 1762 го \\
\hline$S_{\mathrm{p}}$ & Ратманъ / Михаіло Синицынъ * Канцеляристь Петрь Дьячко ${ }^{6}$ \\
\hline
\end{tabular}

\begin{tabular}{|c|c|c|c|c|c|c|c|c|c|c|c|c|c|c|}
\hline 2/11 & \multicolumn{14}{|c|}{ Промемория, 1771 г. [8. С. 371, 372] } \\
\hline \multicolumn{2}{|c|}{$\begin{array}{l}\text { Рекви- } \\
\text { зит }\end{array}$} & \multicolumn{11}{|c|}{ Количество в документе } & \multirow{3}{*}{\multicolumn{2}{|c|}{$\begin{array}{c}\text { «иила знака»: } \\
\text { кол-во слов / кол- } \\
\text { во знаков }\end{array}$}} \\
\hline \multirow{4}{*}{\multicolumn{2}{|c|}{$\begin{array}{c}\text { Рекви- } \\
\text { зит: } \\
\text { предика- } \\
\text { тивная } \\
\text { часть }\end{array}$}} & \multirow{3}{*}{ слов } & \multicolumn{4}{|c|}{ Знаков всего } & \multicolumn{6}{|c|}{ употреблений } & & \\
\hline & & & \multirow{2}{*}{ есть } & \multirow{2}{*}{$\begin{array}{c}\text { могло } \\
\text { бы } \\
\text { быть }\end{array}$} & \multicolumn{2}{|c|}{\begin{tabular}{|c|} 
из них совпа- \\
дает по \\
\end{tabular}} & \multirow[b]{2}{*}{, } & \multirow[b]{2}{*}{ : } & \multirow{2}{*}{\multicolumn{2}{|c|}{$: \mid$}} & \multirow[b]{2}{*}{ - } & \multirow[b]{2}{*}{.1} & & \\
\hline & & & & & месту & \begin{tabular}{|c|} 
функ- \\
ции \\
\end{tabular} & & & & & & & есть & $\begin{array}{c}\text { могло бы } \\
\text { быть }\end{array}$ \\
\hline & & 114 & $\begin{array}{c}7 \\
(63,6 \%) \\
\end{array}$ & 11 & 5 & 2 & - & 1 & 2 & 4 & - & - & 16,28 & $10,36(1,6)^{\mathrm{K}}$ \\
\hline \multirow{2}{*}{\multicolumn{15}{|c|}{\begin{tabular}{l|l}
$\mathrm{N}$ & Промемория :|/ \\
$\mathrm{S}$ & ис Тюме ${ }^{H}$ ской камендантской канцеляриі
\end{tabular}}} \\
\hline & & & & & & & & & & & & & & \\
\hline A $1 \mathrm{E}$ & \multicolumn{14}{|c|}{ 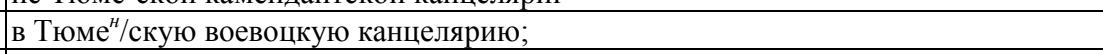 } \\
\hline \begin{tabular}{l|ll}
$\mathrm{K}: 1$ & $\mathrm{I}$ \\
\end{tabular} & \multicolumn{14}{|c|}{ присланною из оной канъ/целяриі промемориею знать дано: } \\
\hline 2,3 & \multicolumn{14}{|c|}{ что оная канъ/целярия за спосо ${ }^{6}$ ное признавае ${ }^{m}<\ldots>$ o $^{m}$ править на $<\ldots>$ поро $/$ мa $^{x}$} \\
\hline P: $4: \mathrm{a}$ & \multicolumn{14}{|c|}{ а потомя $/<\ldots>$ известно и приказано $<\ldots>$ o $^{m}$ правлены буду ${ }^{m} /$} \\
\hline 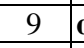 & \multicolumn{14}{|c|}{ о чемъ ко известию ${ }^{ж}$ чрезъ сие и $\operatorname{coo}^{6}$ щае ${ }^{m} ц а$} \\
\hline 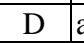 & \multicolumn{14}{|c|}{ апреля / «18» дня «1771» го ${ }^{\text {dy }}:\left.\right|^{*}$} \\
\hline \begin{tabular}{l|l}
$\mathrm{S}_{\mathrm{p}}$ & - \\
\end{tabular} & \multicolumn{14}{|c|}{ Андреи Устьянцовъ Каптенармүс Федо ${ }^{p}$ Лебеде $^{6}$} \\
\hline 3/12 & \multicolumn{14}{|c|}{ Промемория, 1780 г. [8. С. 385, 386] } \\
\hline \multicolumn{2}{|c|}{$\begin{array}{c}\text { Рекви- } \\
\text { зит }\end{array}$} & & & Коли & чество в & докуме & нте & & & & & & $\ll($ & 31 \\
\hline & & & & знако & всего & & & упо & трес & блең & ний & & кол-во & слов / кол- \\
\hline Рекв & & слов & & могло & $\begin{array}{r}\text { из них } \\
\text { дает }\end{array}$ & $\begin{array}{l}\text { совпа- } \\
\text { г по }\end{array}$ & & & & & & & & знаков \\
\hline $\begin{array}{l}\text { преди } \\
\text { тивнс } \\
\text { част }\end{array}$ & ная & & есть & $\begin{array}{c}\text { оЫ } \\
\text { быть }\end{array}$ & месту & \begin{tabular}{|c|} 
функ- \\
ции \\
\end{tabular} & , & : & $: \mid$ & ; & - & $\cdot 1$ & есть & $\begin{array}{c}\text { могло бы } \\
\text { быть }\end{array}$ \\
\hline & & 224 & $2(10 \%)$ & 20 & 1 & 1 & - & - & - & 2 & - & - & 112 & $11,2(10)^{\mathrm{K}}$ \\
\hline \begin{tabular}{l|l}
$N$ & $I$
\end{tabular} & Про & омемс & ория & & & & & & & & & & & \\
\hline \begin{tabular}{l|l}
$S$ & $I$ \\
\end{tabular} & ис T & Гюме & нско ${ }^{\check{u}}$ воев & $0^{\delta}$ скои г & ка ${ }^{H}$ целяр & & & & & & & & & \\
\hline \begin{tabular}{l|l}
$\mathrm{A}$ & $\mathrm{F}$ \\
\end{tabular} & В $\mathrm{TK}_{\mathrm{s}}$ & омен? & ъ/скую коІ & менда ${ }^{H} \mathrm{cl}$ & кую ка ${ }^{H} \mathrm{~L}$ & целярию & & & & & & & & \\
\hline K: 1 C & $\begin{array}{ll}\text { сего } \\
\text { канг }\end{array}$ & $\begin{array}{l}\text { авгу } \\
\text { целяр }\end{array}$ & $\begin{array}{l}\text { ста / } 25 \text { чи } \\
\text { ия требов }\end{array}$ & $\begin{array}{l}{ }^{c} \text { лла при } \\
\text { ала / пр }\end{array}$ & $\begin{array}{l}\text { сланною } \\
\text { ламеморь } \\
\text { омем }\end{array}$ & $\begin{array}{l}\text { в здешн } \\
\text { иеи }\end{array}$ & & & & & & & ая коме & да ${ }^{H}$ ская \\
\hline $2-10 \mid$ & $\begin{array}{ll}<>\mathrm{y} \\
/ \mathrm{KO}\end{array}$ & $\begin{array}{l}\text { унде } \\
\text { что }^{p}\end{array}$ & $\begin{array}{l}\text { афицера }^{M} \\
\text { обучали сл }\end{array}$ & $\begin{array}{l}\text { капрала } \\
\text { повесног }\end{array}$ & $\begin{array}{l}\text { и и саль } \\
\text { и грамот }\end{array}$ & $\begin{array}{l}\text { дата }{ }^{M} / \text { I } \\
\text { е и писа }\end{array}$ & & & & & & & детеи с & вои $^{x}$ свои $^{M}$ \\
\hline \begin{tabular}{l|l} 
P: & \\
11 & $\mathbf{I}$
\end{tabular} & и д & $19 \mathrm{~T}$ & го / в Тюм & $\mathrm{e}^{H} \mathrm{c \kappa o}^{\check{u}}$ в & оеводск & ои ка ${ }^{H} ц е$ & ляр & іи о & пре & дел & ено & & & \\
\hline \begin{tabular}{c|c}
$12-$ & F \\
15 & $\mathrm{c}$
\end{tabular} & $\begin{array}{l}\text { Во о } \\
\text { Что }\end{array}$ & $\begin{array}{l}\text { нную } \\
<\ldots>\end{array}$ & $\begin{array}{l}\text { коменда }{ }^{H} \mathrm{c} \\
\text { приказан }\end{array}$ & $\begin{array}{l}\text { кую ка }{ }^{H} \\
\text { ие чини }\end{array}$ & $\begin{array}{l}\text { целярию } \\
m \text { да и <. }\end{array}$ & $\begin{array}{l}\operatorname{coo}^{6} \text { ши } \\
. .>\text { смо }^{n}\end{array}$ & $\begin{array}{l}\text { ITь } / \\
\text { apeh }\end{array}$ & & & & & & $\begin{array}{l}\text { еи в к } \\
\text { ие им }\end{array}$ & $\begin{array}{l}\text { еи о }{ }^{6} \text { яви } \\
\text { оть } /\end{array}$ \\
\hline \begin{tabular}{l|l}
$\mathrm{D}$ & $\mathrm{a}$ \\
\end{tabular} & авгу & кста 3 & 1 дня 178 & 0 года* & & & & & & & & & & \\
\hline$S_{p}$ & \begin{tabular}{|l} 
Mau \\
Hec
\end{tabular} & $\begin{array}{l}\text { иоръ } \\
\text { теров }\end{array}$ & $\begin{array}{l}\text { Василеи В } \\
\text { зъ* Канцел }\end{array}$ & $\begin{array}{l}\text { ерещаги } \\
\text { ляристь }\end{array}$ & $\begin{array}{l}\text { инъ* Тав } \\
\text { Осипь Н }\end{array}$ & $\begin{array}{l}\text { зарищъ I } \\
\text { Нестеров }\end{array}$ & Петा & & & & & & pe & Яко ${ }^{6}$ \\
\hline
\end{tabular}


В этих и многих других промемориях [20, 21, 22] волеизъявление коллегиального адресанта S (воеводская или комендантская канцелярия, магистрат или духовное правление) коллегиальному же адресату А (те же присутственные места) вводится в текст, как правило, безличной конструкцией с кратким страдательным причастием определено или велено, приказано + имя А в форме Дат.п., реже - этикетной личной глагольной формой благоволит (да благоволит) + имя А в форме Им.П., или - безадресно: конструкцией неопределенно-личного предложения с глагольной формой $n p u$ казали или безличного предложения требуется - во всех случаях, как и в документах других жанров, с последующей системой зависимых инфинитивов, называющих требуемые от адресата действия.

Результаты анализа промеморий вновь демонстрируют преимущественное выделение знаком препинания в тексте формулярно значимой границы сфер разных субъектов речи, что сопровождается изменением текстовой модальности как следствия изменения коммуникативных интенций субъектов документооборота.

\section{Выводы}

Проведенное исследование функционирования знаков препинания в скорописных документах последней трети XVIII в. позволило сформулировать следующие выводы.

1. Пунктуационное оформление тюменских скорописных документов 1762-1796 гг. к концу анализируемого периода претерпевает значительные изменения. Резкое увеличение использования знаков препинания происходит на границе 1760-1770-х гг. В это время до 87,5\% (против 64,1\% в предыдущее десятилетие) возрастает число документов, в принципе имеющих пунктуационные знаки, и до 90\% - количество документов с двумя и более (до 265) знаками. В последующие три десятилетия эти показатели в значительной степени сохраняются. Конец XVIII в. характеризуется увеличением доли документов (без учета жанровой принадлежности) с максимальной пунктуационной насыщенностью: в среднем каждый шестой документ содержал от 11 до 20 знаков препинания, каждый восьмой - от 21 до 30 знаков.

2. В исследованном материале наблюдается определенная жанровая корреляция в употреблении и распределении знаков препинания на границах реквизитов абстрактного формуляра документа (рис. 1).

Во всех четырех жанрах приоритет пунктуационного оформления - y внутритекстовой границы казусной и прагматической частей, фиксирующей смену субъекта речи и текстовой модальности. Следующей пунктуационно отмеченной границей реквизитов для предложений, доношений и объявлений (документов с персонифицированными субъектами устного волеизъявления, составленных, как правило, профессиональными субъектами письма) является абсолютный конец реквизита «Текст» и переход к реквизиту «Подпись», выполненному чаще всего другим почерком - почерком субъекта речи (волеизъявления). 


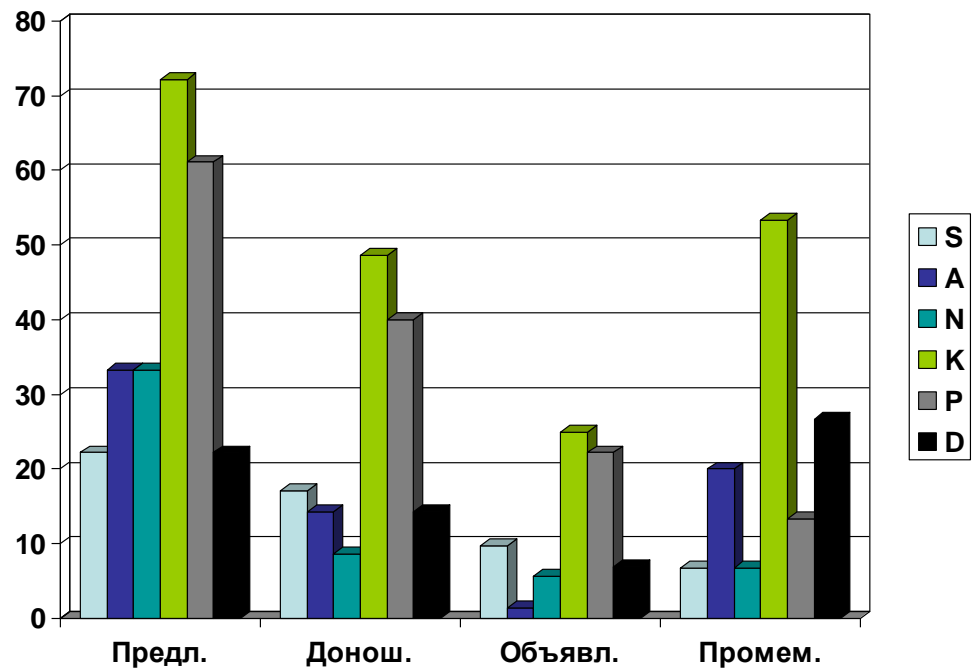

Рис. 1. Употребление (в процентном выражении)

и распределение знаков препинания на границах реквизитов абстрактного формуляра документов четырех жанров

Для промеморий более значимым оказывается пунктуационное выделение реквизита «Дата», которым фиксируется этап межканцелярского документооборота между коллегиальными субъектами речи / письма в их профессиональной дистанционной коммуникации. При этом важно отметить неизменность иерархии положения в административном пространстве и коммуникативной роли субъектов делового общения, оформленного документами первой группы (предложения и др.), и постоянную смену коммуникативных ролей рядоположенных адресанта и адресата промеморий.

3. Следовательно, изменение коммуникативных интенций в деловом тексте, отражаемое формуляром документа, чаще воспринимается субъектом письма как нуждающееся в достаточно сильном пунктуационном «подкреплении» (см. данные табл. 9). Таковым может быть и абзацное членение, очень редко встречающееся в документах (пример - доношение 1/4).

Т а б ли ц а 9

Пунктуационное оформление реквизитов разными знаками препинания

\begin{tabular}{|c|c|c|c|c|c|c|c|c|}
\hline \multirow{2}{*}{$\begin{array}{l}\text { Рекви- } \\
\text { зит } \\
\end{array}$} & \multicolumn{7}{|c|}{ Знак препинания (абсолютное число) } & \multirow{2}{*}{ Всего } \\
\hline & , & ; & : & : & .1 & . & ? & \\
\hline $\mathbf{S}$ & 8 & 3 & 4 & 3 & - & - & - & $18(11,32 \%)$ \\
\hline $\mathbf{A}$ & 5 & 1 & 1 & - & 2 & 2 & - & $11(6,92 \%)$ \\
\hline $\mathbf{N}$ & 5 & - & 3 & 1 & - & 2 & - & $11(6,92 \%)$ \\
\hline $\mathbf{K}$ & 20 & 18 & 10 & 5 & - & 3 & - & $56(35,22 \%)$ \\
\hline $\mathbf{P}$ & 16 & 4 & 4 & 10 & 5 & 3 & 1 & $43(27,05 \%)$ \\
\hline D & 4 & 1 & 3 & 6 & 3 & 1 & - & $18(11,32 \%)$ \\
\hline$S_{p}$ & 1 & - & - & 1 & - & - & - & $2(1,25 \%)$ \\
\hline ИТОГО & $\begin{array}{c}59 \\
(37,15 \%)\end{array}$ & $\begin{array}{c}27 \\
(16,98 \%)\end{array}$ & $\begin{array}{c}25 \\
(15,7 \%)\end{array}$ & $\begin{array}{c}26 \\
(16,35 \%)\end{array}$ & $\begin{array}{c}10 \\
(6,28 \%)\end{array}$ & $\begin{array}{c}11 \\
(6,92 \%)\end{array}$ & $\begin{array}{c}1 \\
(0,62 \%)\end{array}$ & $159(100 \%)$ \\
\hline
\end{tabular}


4. Все реквизиты начального и конечного протоколов получают максимальное пунктуационное оформление в документах жанра предложение и минимальное - в объявлениях (рис. 2, 3).

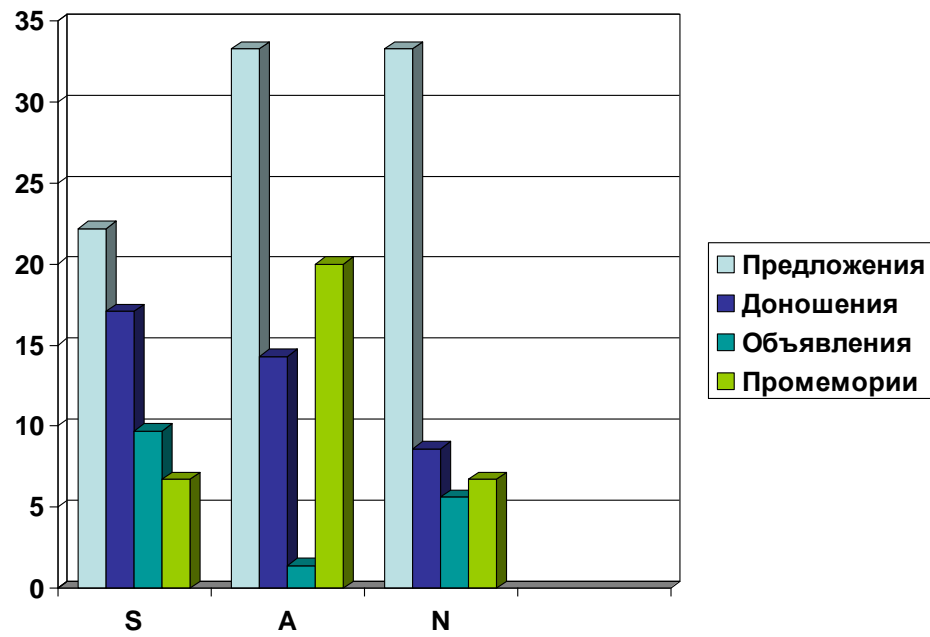

Рис. 2. Пунктуационное оформление реквизитов

начального протокола ( $\mathrm{S}$ - формула адресанта, $\mathrm{A}$ - формула адресата, $\mathrm{N}$ - самоназвание документа) в процентном выражении

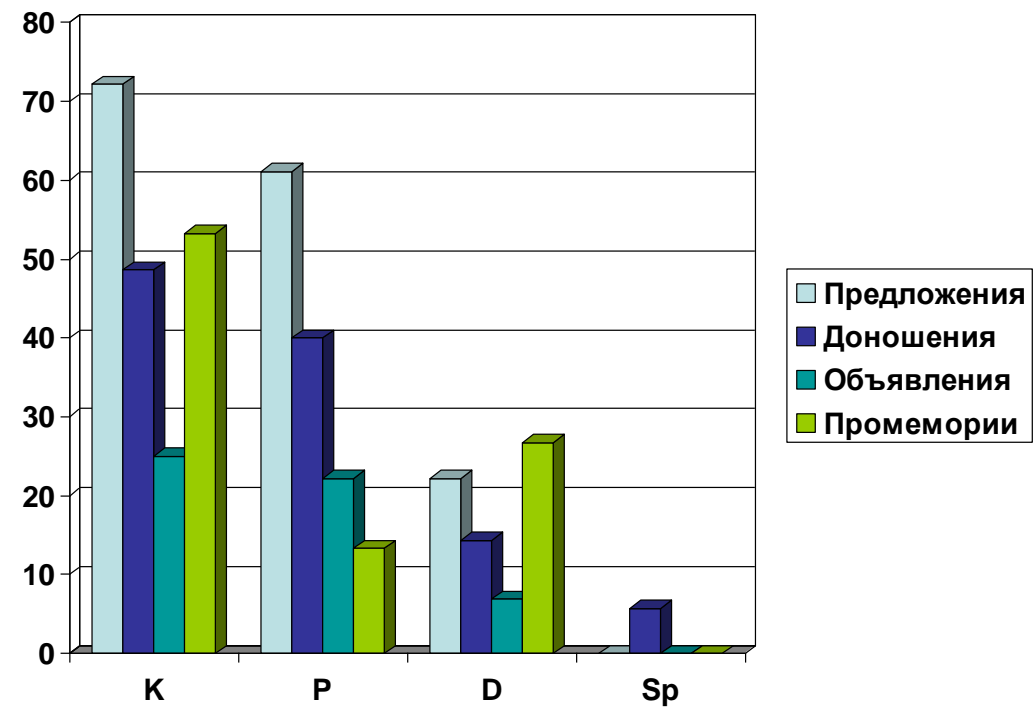

Рис. 3. Пунктуационное оформление реквизитов текстового блока и конечного протокола $(\mathrm{K}$ - казусная часть, $\mathrm{R}$ - прагматическая часть, $\mathrm{D}$ - дата, $\mathrm{S}_{\mathrm{p}}$ - подпись) в процентном выражении 
Эти жанры могут быть противопоставлены по степени свободы персонифицированного адресанта от соблюдения формулярных «рамок» деловой коммуникации: минимальной у высшего должностного лица и максимальной у свободного от административных функций «обывателя».

5. Формулярные блоки (реквизиты) документа, разделенные знаком препинания, нередко не имеют внутренней «пунктуационной разметки». Таким образом, в пунктуационном оформлении 139 тюменских скорописных документов четырех жанров преимущество - у формулярного принципа перед интонационно-грамматическим.

6. Самым частотным знаком препинания в анализируемом материале, занимающим любую позицию в формуляре документа любого жанра, является запятая. На границе казусной и прагматической частей, как правило, ставили почти так же часто, как запятую, точку с запятой и в два раза реже - двоеточие. В конце реквизита «Текст» в скорописном документе последней трети XVIII в. вероятнее всего встретить запятую или сроку, хотя именно в этой формулярной позиции можно обнаружить любой из семи перечисленных в табл. 9 знаков препинания.

\section{Лumepamypa}

1. Валгина Н.С. Русская пунктуация: принципы и назначение. М. : Просвещение, 1979. $125 \mathrm{c}$.

2. Иванова В.Ф. История и принципы русской пунктуации. Л. : Изд-во Ленингр. унта, $1962.64 \mathrm{c}$.

3. Шапиро А.Б. Основы русской пунктуации. М. : Изд-во Академии наук СССР, $1955.398 \mathrm{c}$.

4. Трофимова O.B. Русский документ XVIII века: пунктуация рукописного оригинала и его транслитерированной публикации // Annales Universitatis Paedagogicae Cracoviensis. Studia Russologica VII. Folia 179. Kraków : Wydawnictwo Naukowe UP, 2014. C. $57-71$.

5. Щерба Л.В. Теория русского письма. Л. : Наука, 1983. 134 с.

6. Зиндер Л.Р. Очерк общей теории письма. Л. : Наука, 1987. 112 с.

7. Данилевский Н.И. и др. Источниковедение: Теория. История. Метод. Источники российской истории. М. : Рос. гос. гуманит. ун-т, 1998. 702 с.

8. Трофимова O.B. Тюменская деловая письменность. 1762-1796 гг. Кн. 2: Памятники тюменской деловой письменности. Из фондов Государственного архива Тюменской области. Тюмень : Изд-во Тюм. гос. ун-та, 2002. 828 с.

9. Трофимова О.В. Тюменская деловая письменность. 1762-1796 гг. Кн. 3: Тюменские рукописные деловые тексты 1762-1796 гг. в аспектах лингвистики и документоведения: лингвистический анализ текста. Тюмень : Вектор Бук, 2002. 232 с.

10. Васева Д.Д. Языковые средства формирования смысловой структуры художественного текста (на материале современного рассказа) : дис. ... канд. филол. наук. СПб., 2018. 203 с.

11. Кубрякова E.C. О тексте и критериях его определения. URL: http://www.philology.ru/ linguistics1/kubryakova-01.htm (дата обращения: 07.06.2020).

12. Живов B.M. История языка русской письменности : в 2 т. М. : Русский фонд содействия образованию и науке, 2017. Т. 1.816 с.

13. Словарь Академии Российской. Часть 3. СПб. : Императорская Академия наук, 1792. URL: https://runivers.ru/bookreader/book10109/\#page/646/mode/1up (дата обращения: 07.06.2020). 
14. Словарь Академии Российской. Ч. 4. СПб. : Императорская Академия наук, 1793. URL: https://runivers.ru/bookreader/book10110/\#page/251/mode/1up (дата обращения: 07.06.2020).

15. Краткий словарь видов и разновидностей документов / отв. ред. А.С. Малитиков. М. : [б. и.], 1974. 79 с.

16. Словарь русского языка XVIII века. Вып. 6 (Грызться - Древний) / гл. ред. Ю.С. Сорокин. Л. : Наука, 1991. 256 с.

17. Словарь Академии Российской. СПб. : Императорская Академия Наук, 1794. Ч. 6. URL: https://runivers.ru/bookreader/book10112/\#page/518/mode/1up (дата обращения: 07.06.2020).

18. Словарь русского языка XVIII века. Вып. 16 (Обломить - Онца) / гл. ред. 3.М. Петрова. СПб. : Наука, 2006. 278 с.

19. Трофимова O.B. Объявления жителей Тюмени как реализация жанра деловой письменности XVIII века (на материале объявлений о кражах) // Славянские истоки словесности и культуры в Западной Сибири. Тюмень, 2002. Ч. 1. С. 68-76.

20. Трофимова O.B. Континуальность и дискретность текста промемории // Континуальность и дискретность в языке и речи : материалы 2-й Междунар. науч. конф. Краснодар, 2009. С. 197-198.

21. Трофимова O.B. Синтаксический строй русских промеморий // Русский язык: система и функционирование (к 90-летию БГУ и 85-летию профессора П.П. Шубы) : сб. материалов 5-й Междунар. научн. конф., 11-12 октября 2011 г. Минск, 2011. С. 96-99.

22. Трофимова O.B. Структура и семантика русских промеморий // Русский язык: функционирование и развитие (к 85-летию со дня рождения заслуженного деятеля науки Российской Федерации профессора Виталия Михайловича Маркова) : материалы Междунар. науч. конф., Казань, 18-21 апреля 2012 г. Казань, 2012. Т. 1. С. 344-350.

23. Трофимова O.B. Того ради и другие союзные средства выражения цели в документах разных жанров (на материале тюменской деловой письменности последней трети XVIII в.) // Вестник Тюменского государственного университета. 2000. № 4. C. $45-60$.

24. ГБУТО ГАТО. Ф. И-6. Оп. 1. Д. 281. Л. 20; Д. 782. Л. 21, 21 об.; Д. 916. Л. 3; Ф. И-10. Оп. 1. Д. 4511. Л. 2; Ф. И-47. Оп. 1. Д. 3585. Л. 23, 30, 88; Д. 4848. Л. 65.

25. Полное собраніе законовъ Россійской Имперіи, съ 1649 года. Т. 6: 1720-1722. Печатано въ Типографіи II Отдъленія Собственной Его Императорскаго Величества Канцеляріи, 1830. URL: http://nlr.ru/e-res/law_r/search.php (дата обращения: 07.06.2020).

26. ГБУТО ГАТО. Ф. И-3. Оп. 1. Д. 191. Л. 240, 241 об., 245, 245 об., 385, 385 об., 716; Д. 647. Лл. 274, 274 об., 278, 278 об., 285, 285 об.; Ф. И-6. Оп. 1. Д. 25. Л. 256, 256 об.; Д. 755. Л. 73, 100; Ф. И-10. Оп. 1. Д. 386. Л. 47, 49; Ф. И-47. Оп. 1. Д. 1761. Л. 101, 101 об.; Д. 1769. Л. 24; Д. 3351. Л. 1; Д. 3509. Л. 47, 47 об.; Д. 3585. Л. 24, 24 об.; Д. 3670. Л. 2, 2 об.; Д. 4457. Л. 1.

27. ГБУТО ГАТО. Ф. И-3. Оп. 1. Д. 647. Л. 293-294 об.

28. ГБУТО ГАТО. Ф. И-3. Оп.1. Д. 410. Л. 4; Д. 645. Л. 1-3 об.; Д. 647. Л. 8-10 об., 12, 12 об., 14-16 об., 26, 26 об., 66, 66 об., 75, 110, 110 об., 122, 144, 144 об., 162, 162 об., 184, 184 об., 217, 223-225, 248, 250, 252, 253, 256-257 об., 259, 266, 269-270 об., 275277, 286, 289-290, 315, 315 об., 319-320, 333, 378-380, 389, 389 об., 400, 400 об., 542, 711; Ф. И-47. Оп. 1. Д. 4356. Л. 1, 1 об.; Ф. И-86. Оп. 1. Д. 71. Л. 1, 1 об.

A Study on Punctuation in the Russian Document in the Formulaic Aspect: A Case of Tyumen Business Documents Dating Back to the Last Third of the 18th Century

Vestnik Tomskogo gosudarstvennogo universiteta. Filologiya - Tomsk State University Journal of Philology. 2021. 70. 137-165. DOI: 10.17223/19986645/70/8

Olga V. Trofimova, Tyumen State University (Tyumen, Russian Federation). E-mail: otrofim@rambler.ru 
Keywords: punctuation, history of Russian language, grammar, language of business documents, cursive handwriting.

The article addresses the formation of the Russian punctuation system and its dynamics over time. The research draws upon 450 archival documents of 82 genres preserved in the State Archive of Tyumen Oblast; some of them were published earlier by the author and others are introduced into the academic discourse for the first time. It was found that, during the reign of Catherine II (1762-1796), punctuation marks in Tyumen business documents had undergone significant changes in their quantity. As opposed to the $1760 \mathrm{~s}$, when every third document had no punctuation marks and the rest $35 \%$ had only one, at the end of the 18th century, only every seventh cursive business document was devoid of punctuation and twice as less (19\%) documents contained only one punctuation mark. The study employs a grammatical-diplomatic method of analysis based on a formulaic analysis of the document structure by its distinctive structural components. It was established that structural parts of business documents could be marked by any punctuation mark: comma, semicolon, colon, etc. Tendencies in the "specialization" of punctuation marks depending on their use in the introductory, main or final part of the business document were identified. It is argued that the main reason for adding punctuation marks to written business communication is a change in the text modality. Grammatical expression of volition in the pragmatic section of the main body of a document is often associated with a change of the writer/speaker. The article presents a classification of subjects of the oral and written speech in question, who, as a rule, are different in the studied documents. The author of the research compared and described how punctuation marks function in the documents of four genres: proposals (administrative types of documents), pro memoria (types of reports), announcements and notifications (belong to request and report types). Genre correlation in the use and distribution of punctuation marks at the end of the structural parts of an abstract document was found. In proposals, reports and announcements (documents with personalized subjects of the oral expression of volition), the end of the main body is more often marked by a punctuation mark to show transition to the "signature" part. As a rule, at this point, the main handwriting of the document (the handwriting of the scrivener) changes to the handwriting of the subject of speech (subject of the volition). In pro memoria, the most important part of the document in terms of punctuation is the date which reflects the stage of the document flow between colleagues, subjects of speech/writing (various offices) in their professional correspondence.

\section{References}

1. Valgina, N.S. (1979) Russkaya punktuatsiya: printsipy $i$ naznachenie [Russian punctuation: principles and purpose]. Moscow: Prosveshchenie.

2. Ivanova, V.F. (1962) Istoriya i printsipy russkoy punktuatsii [History and principles of Russian punctuation]. Leningrad: Leningrad State University.

3. Shapiro, A.B. (1955) Osnovy russkoy punktuatsii [Basics of Russian punctuation]. Moscow: USSR AS.

4. Trofimova, O.V. (2014) Russkiy dokument XVIII veka: punktuatsiya rukopisnogo originala i ego transliterirovannoy publikatsii [Russian document of the 18th century: punctuation of the manuscript original and its transliterated publication]. In: Annales Universitatis Paedagogicae Cracoviensis. Studia Russologica VII. Folia 179. Kraków: Wydawnictwo Naukowe UP. pp. 57-71.

5. Shcherba, L.V. (1983) Teoriya russkogo pis'ma [The theory of Russian writing]. Leningrad: Nauka.

6. Zinder, L.R. (1987) Ocherk obshchey teorii pis'ma [An outline of the general theory of writing]. Leningrad: Nauka. 
7. Danilevskiy, N.I. et al. (1998) Istochnikovedenie: Teoriya. Istoriya. Metod. Istochniki rossiyskoy istorii [Source study: Theory. History. Method. Sources of Russian history]. Moscow: RSUH.

8. Trofimova, O.V. (2002) Tyumenskaya delovaya pis 'mennost'. 1762-1796 gg. [Tyumen business writing. 1762-1796]. Book 2. Tyumen: Tyumen State University.

9. Trofimova, O.V. (2002) Tyumenskaya delovaya pis'mennost'. 1762-1796 gg. [Tyumen business writing. 1762-1796]. Book 3. Tyumen: Vektor Buk.

10. Vaseva, D.D. (2018) Yazykovye sredstva formirovaniya smyslovoy struktury khudozhestvennogo teksta (na materiale sovremennogo rasskaza) [Linguistic means of forming the semantic structure of a literary text (based on the material of the modern short story)]. Philology Cand. Diss. St. Petersburg.

11. Kubryakova, E.S. (2001) O tekste i kriteriyakh ego opredeleniya [On the text and the criteria for its definition]. [Online] Available from: http://www.philology.ru/ linguistics1/kubryakova-01.htm (Accessed: 07.06.2020).

12. Zhivov, V.M. (2017) Istoriya yazyka russkoy pis'mennosti: $v 2 t$. [History of the language of Russian writing: in 2 volumes]. Vol. 1. Moscow: Russkiy fond sodeystviya obrazovaniyu i nauke.

13. Imperial Academy of Sciences. (1792) Slovar' Akademii Rossiyskoy [Dictionary of the Russian Academy]. Part 3. St. Petersburg: Imperial Academy of Sciences. [Online] Available from: https://runivers.ru/bookreader/book10109/\#page/646/mode/1up (Accessed: 07.06.2020).

14. Imperial Academy of Sciences. (1793) Slovar' Akademii Rossiyskoy [Dictionary of the Russian Academy]. Part 4. St. Petersburg: Imperial Academy of Sciences. [Online] Available from: https://runivers.ru/bookreader/book10110/\#page/251/mode/1up (Accessed: 07.06.2020).

15. Malitikov, A.S. (ed.) (1974) Kratkiy slovar' vidov i raznovidnostey dokumentov [A concise dictionary of types and varieties of documents]. Moscow: [s.n.].

16. Sorokin, Yu.S. (ed.) (1991) Slovar' russkogo yazyka XVIII veka [Dictionary of the Russian language of the 18th century]. Vol. 6. Leningrad: Nauka.

17. Imperial Academy of Sciences. (1794) Slovar' Akademii Rossiyskoy [Dictionary of the Russian Academy]. Part 6. St. Petersburg: Imperial Academy of Sciences. [Online] Available from: https://runivers.ru/bookreader/book10112/\#page/518/mode/1up (Accessed: 07.06.2020).

18. Petrova, Z.M. (ed.) (2006) Slovar' russkogo yazyka XVIII veka [Dictionary of the Russian language of the 18th century]. Vol. 16. St. Petersburg: Nauka.

19. Trofimova, O.V. (2002) Ob"yavleniya zhiteley Tyumeni kak realizatsiya zhanra delovoy pis'mennosti XVIII veka (na materiale ob"yavleniy o krazhakh) [Announcements of residents of Tyumen as a realization of the genre of business writing of the 18th century (based on announcements of thefts)]. In: Slavyanskie istoki slovesnosti i kul'tury v Zapadnoy Sibiri [Slavic sources of literature and culture in Western Siberia]. Vol. 1. Tyumen: [s.n.]. pp. $68-76$.

20. Trofimova, O.V. (2009) [Continuity and discreteness of the text of the pro memoria]. Kontinual'nost' $i$ diskretnost' $v$ yazyke i rechi [Continuity and discreteness in language and speech]. Proceedings of the International Conference. Krasnodar: Kuban State University. pp. 197-198. (In Russian).

21. Trofimova, O.V. (2011) [Syntactic structure of Russian pro memoria]. Russkiy yazyk: sistema i funktsionirovanie (k 90-letiyu BGU i 85-letiyu professora P.P. Shuby) [Russian language: system and functioning (to the 90th anniversary of BSU and 85th anniversary of Professor P.P. Shuba)]. Proceedings of the International Conference. Minsk. 11-12 October 2011. Minsk: Belarusian State University. pp. 96-99. (In Russian).

22. Trofimova, O.V. (2012) [Structure and semantics of Russian pro memoria]. Russkiy yazyk: funktsionirovanie i razvitie ( $k$ 85-letiyu so dnya rozhdeniya zasluzhennogo deyatelya nauki Rossiyskoy Federatsii professora Vitaliya Mikhaylovicha Markova) [Russian language: functioning and development (to the 85th anniversary of the birth of Professor Vitaly Markov, Honored Scientist of the Russian Federation)]. Proceedings of the International Conference. Kazan. 18-21 April 2012. Vol. 1. Kazan. pp. 344-350. (In Russian). 
23. Trofimova, O.V. (2000) Togo radi i drugie soyuznye sredstva vyrazheniya tseli $\mathrm{v}$ dokumentakh raznykh zhanrov (na materiale tyumenskoy delovoy pis'mennosti posledney treti XVIII v.) [Togo radi and other conjunctions expressing goals in documents of different genres (based on the Tyumen business writing of the last third of the 18th century)]. Vestnik Tyumenskogo gosudarstvennogo universiteta - Bulletin of Tyumen State University. 4. pp. 45-60.

24. State Archive of Tyumen Oblast. Fund I-6. List 1. File 281. P. 20; File 782. P. 21, 21 rev.; File 916. P. 3; Fund I-10. List 1. File 4511. P. 2; Fund I-47. List 1. File 3585. P. 23, 30, 88; File 4848. P. 65.

25. Russian Empire. (1830) Polnoe sobranie zakonov" Rossiyskoy Imperii, s" 1649 goda [Complete collection of laws of the Russian Empire, from 1649]. Vol. 6: 1720-1722. Pechatano v" Tipografii II Otdbleniya Sobstvennoy Ego Imperatorskago Velichestva Kantselyarii. [Online] Available from: http://nlr.ru/e-res/law_r/search.php (Accessed: 07.06.2020).

26. State Archive of Tyumen Oblast. Fund I-3. List 1. File 191. P. 240, 241 rev., 245, 245 rev., 385, 385 rev., 716; File 647. P. 274, 274 rev., 278, 278 rev., 285, 285 rev.; Fund I-6. List 1. File 25. P. 256, 256 rev.; File 755. P. 73, 100; Fund I-10. List 1. File 386. P. 47, 49; Fund I47. List 1. File 1761. P. 101, 101 rev.; File 1769. P. 24; File 3351. P. 1; File 3509. P. 47, 47 rev.; File 3585. P. 24, 24 rev.; File 3670. P. 2, 2 rev.; File 4457. P. 1.

27. State Archive of Tyumen Oblast. Fund I-3. List 1. File 647. P. 293-294 rev.

28. State Archive of Tyumen Oblast. Fund I-3. List1. File 410. P. 4; File 645. P. 1-3 rev.; File 647. P. 8-10 rev., 12, 12 rev., 14-16 rev., 26, 26 rev., 66, 66 rev., 75, 110, 110 rev., 122, 144, 144 rev., 162, 162 rev., 184, 184 rev., 217, 223-225, 248, 250, 252, 253, 256-257 rev., 259, 266, 269-270 rev., 275-277, 286, 289-290, 315, 315 rev., 319-320, 333, 378-380, 389, 389 rev., 400, 400 rev., 542, 711; Fund I-47. List 1. File 4356. P. 1, 1 rev.; Fund I-86. List 1. File 71. P. 1, 1 rev. 